Portland State University

PDXScholar

Environmental Science and Management

Faculty Publications and Presentations

\title{
Effectiveness of Forest Management Strategies to Mitigate Effects of Global Change in South-Central Siberia
}

Eric J. Gustafson

US Department of Agriculture Forest Service

Anatoly Z. Shvidenko

International Institute for Applied Systems Analysis

Robert M. Scheller

Portland State University, rmschell@pdx.edu

Follow this and additional works at: https://pdxscholar.library.pdx.edu/esm_fac

Part of the Environmental Sciences Commons, and the Forest Sciences Commons Let us know how access to this document benefits you.

\section{Citation Details}

Gustafson, E. J., Shvidenko, A. Z., \& Scheller, R. M. (2011). Effectiveness of forest management strategies to mitigate effects of global change in south-central Siberia. Canadian Journal Of Forest Research, 41(7), 1405-1421. doi:10.1139/x11-065

This Article is brought to you for free and open access. It has been accepted for inclusion in Environmental Science and Management Faculty Publications and Presentations by an authorized administrator of PDXScholar. Please contact us if we can make this document more accessible: pdxscholar@pdx.edu. 


\title{
Effectiveness of forest management strategies to mitigate effects of global change in south-central Siberia
}

\author{
Eric J. Gustafson, Anatoly Z. Shvidenko, and Robert M. Scheller
}

\begin{abstract}
We investigated questions about the ability of broad silvicultural strategies to achieve multiple objectives (reduce disturbance losses, maintain the abundance of preferred species, mitigate fragmentation and loss of age-class diversity, and sequester aboveground carbon) under future climate conditions in Siberia. We conducted a factorial experiment using the LANDIS-II landscape disturbance and succession model. Treatments included varying the size and amount of areas cut and the cutting method (selective or clearcut). Simultaneously, the model simulated natural disturbances (fire, wind, insect outbreaks) and forest succession under projected future climate conditions as predicted by an ensemble of global circulation models. The cutting method and cutting rate treatments generally had a large effect on species and age-class composition, residual living biomass, and susceptibility to disturbance, whereas cutblock size had no effect. Cutblock size affected only measures of fragmentation, but cutting method and cutting rate often had an even greater effect. Based on the results, we simulated a "recommended" strategy and compared it with the current forest management practice. The recommended strategy resulted in greater forest biomass, increased abundance of favored species, and reduced fragmentation, but it did not significantly reduce losses by disturbance. No single strategy appears able to achieve all possible forest management objectives.
\end{abstract}

Résumé : Nous avons étudié certaines questions concernant la capacité des grandes stratégies sylvicoles à atteindre des objectifs multiples (réduire les pertes dues aux perturbations, conserver l'abondance des espèces préférées, réduire la fragmentation et la perte de diversité des classes d'âge et séquestrer le carbone aérien) dans les conditions climatiques à venir en Sibérie. Nous avons réalisé une expérience factorielle à l'aide du modèle de perturbation du paysage et de succession LANDIS-II. Les traitements incluaient diverses dimensions et quantités d'aires de coupe ainsi que la méthode de coupe (coupe rase ou de jardinage). Le modèle simulait en même temps les perturbations naturelles (feu, vent, épidémie d'insectes) et la succession forestière dans les conditions climatiques à venir telles que prédites par un ensemble de modèles de circulation générale. La méthode de coupe et le taux de récolte avaient généralement un effet important sur la composition en espèces et en classes d'âge, la biomasse vivante résiduelle et la prédisposition aux perturbations, tandis que la dimension de l'aire de coupe n'avait aucun effet. La dimension de l'aire de coupe avait un effet seulement sur les mesures de fragmentation mais la méthode de coupe et le taux de récolte avaient souvent un effet encore plus grand. Sur la base des résultats, nous avons simulé une stratégie à recommander et nous l'avons comparée aux pratiques courantes d'aménagement forestier. La stratégie à recommander a engendré une plus grande quantité de biomasse forestière, une augmentation de l'abondance des espèces préférées et une réduction de la fragmentation mais elle n'a pas réduit de façon significative les pertes dues aux perturbations. Aucune stratégie ne semble en mesure de satisfaire tous les objectifs possible d'aménagement forestier.

[Traduit par la Rédaction]

\section{Introduction}

Multiple global changes are impacting forested ecosystems around the world. These changes are not uniform across the globe, nor are their effects. For example, clearing of previously undisturbed tropical forests often results in long-term deforestation, whereas clearcutting of pristine boreal forests is usually followed by natural regeneration of an early successional forest type (Betts et al. 2008). Similarly, climate change is more rapid at higher latitudes (Intergovernmental Panel on Climate Change (IPCC) 2007), and direct and indirect effects, e.g., longer and more severe fire seasons (Miller et al. 2009; Westerling et al. 2006; Soja et al. 2007) and increased insect outbreaks as cold-weather events that limit insect populations become fewer (Juday et al. 2005), may already be occurring.

Global changes produce direct and indirect effects on forested ecosystems, and these interact with multiple natural

Received 9 August 2010. Accepted 20 January 2011. Published at www.nrcresearchpress.com/cjfr on 5 July 2011.

E.J. Gustafson. Institute for Applied Ecosystem Studies, USDA Forest Service, Northern Research Station, 5985 Highway K, Rhinelander, WI 54501, USA.

A.Z. Shvidenko. International Institute for Applied Systems Analysis, Schlossplatz 1, A-2361 Laxenburg, Austria.

R.M. Scheller. Portland State University, Department of Environmental Sciences and Management, P.O. Box 751, Portland, OR 97207, USA.

Corresponding author: Eric J. Gustafson (e-mail: egustafson@ fs.fed.us). 
and anthropogenic disturbances and other ecological processes such as succession. Predicting the cumulative impacts of such complex interactions is difficult and usually requires an integrative modeling approach (Milne et al. 2009). When the drivers of ecosystem dynamics substantially shift (e.g., climate change), a process-based modeling approach is required. The LANDIS-II (LANDscape DIsturbance and Succession) model is ideally suited to such problems because it models multiple ecological and anthropogenic processes such that the interactions of these processes are an emergent property of the simulations (Mladenoff 2004). LANDIS-II can be linked to the outputs of atmosphere-ocean global circulation models (GCMs) to allow climate change to interact with landscape processes in the simulation environment (Gustafson et al. 2010).

An example of a high-latitude forested ecosystem that is experiencing multiple global changes is the boreal forest of Siberian Russia (Soja et al. 2007). These forests are vast and sequester a large amount of carbon (Hom 2003). Much of their area has not yet been subject to timber harvest, but the frontier of timber cutting is advancing steadily across the region. Furthermore, mean temperatures have risen significantly in Siberia over the past 40 years, and this trend is expected to continue (Vaschuk and Shvidenko 2006). Recent precipitation trends are less clear, with a statistically insignificant negative trend during the growing season (Vaschuk and Shvidenko 2006). An expected consequence of this warming is an increase in outbreaks of the Siberian silk moth (Dendrolimus sibiricus superanse), which defoliates and kills conifers. Gustafson et al. (2010) projected the effect of these global changes on forest composition, landscape pattern, and aboveground carbon storage in south-central Siberia. They found that the combined effect of these global changes is likely to result in significant changes to forest composition and that harvesting and insect outbreaks, in particular, may take these ecosystems outside their historic range of natural variability (HRNV).

There are several components of timber harvest strategies that significantly impact forest composition and spatial pattern (Gustafson 2007), namely cutblock size, cutting rate, and silvicultural method (e.g., clearcut vs. partial cut) (Gustafson and Crow 1994; Gustafson 2007; Radeloff et al. 2006). Under the Russian Forest Code, cutblock size in nonmountainous areas is currently limited to 50 ha (Ministry of Natural Resources of the Russian Federation 2007b). The cutting rate for each administrative unit is limited by the Annual Allowable Cut, which is set by local forest enterprises using procedures defined by the Russian Ministry of Natural Resources, such that harvest levels do not exceed mean annual increment and that the supply of mature and over-mature stands can be sustained for at least 40 years (Ministry of Natural Resources of the Russian Federation 2007a). However, forests are rarely cut at this maximum allowable rate, usually because of poorly developed infrastructure. The silvicultural method employed for removing timber is determined by the application of management guides (Ministry of Natural Resources of the Russian Federation 2007b). Although Siberian pine (Pinus sibirica Du Tour), known as kedar in Russia, is currently protected from most logging, many scientists and forest managers consider this ban to be excessive and even ecologically deleterious (e.g., Sedykh 2009). Therefore, it is possible that (mostly selection) cutting of this species may be permitted in the near future. Although these timber harvest regulations are codified in the Russian Forest Code to make timber removal sustainable under historic conditions, there is potentially some flexibility to achieve forest sustainability goals under future conditions.

The objective of our study was to evaluate the effect of various strategic forest management options on major forest characteristics under future climate conditions in Siberia. We used LANDIS-II to conduct a factorial experiment manipulating three factors representing timber cutting strategies (cutting method, cutting rate, cutblock size) to determine their effect on forest composition, fragmentation, carbon sequestration, harvest volume, and area affected by natural disturbance. We incorporated a changing climate and increased insect outbreaks similar to Gustafson et al. (2010). We specifically wished to determine if the management options significantly affect our response variables and the relative strength of the relationships between management strategies and each response variable in the face of climate change. The results can shed light on the following important questions.

1. What is the relative effect of various silvicultural techniques on forest composition, standing biomass, and landscape pattern?

2. Can silviculture reduce the susceptibility of forests to natural disturbance (wildfire and silk moth) under future climate conditions?

3. Can management increase forest productivity under future climate and disturbance regimes?

4. What are the effects of silvicultural strategy on carbon sequestration?

5. Can management actions effectively keep ecosystem dynamics within the HRNV?

\section{Methods}

\section{Overview of the experimental design}

We conducted a factorial experiment using LANDIS-II by manipulating three variables that are under management control. The METHOD treatment varied the harvesting method (clearcut and selection cut, i.e., partial biomass removal), the RATE treatment varied the harvesting rate $(2.5 \%$ and $5 \%$ of the forested area harvested per decade), and the CUTBLOCK treatment varied cutblock size (25 ha and 100 ha). Simultaneously, the model simulated natural disturbances (fire, wind, insect outbreaks) and forest succession under projected future climate conditions as predicted by an ensemble of four GCMs (see below), with the parameters for these processes held constant among treatments. Each treatment was simulated for 300 years (approximately three rotations), with three replicates. The relative effect of the treatments on forest composition, biomass, fragmentation, and the level of natural disturbance was assessed using multivariate analysis of variance.

\section{Study area}

We conducted the study on a 316527 ha study area in south-central Siberia (Fig. 1). It is located in the ChunoAngarsky sub-ecoregion at the boundary between the southern and middle taiga bioclimatic zones (Vaschuk and Shvidenko 2006). Soils are mostly homogeneous and are 
Fig. 1. Location of the study area, centered at $58.9^{\circ} \mathrm{N}, 103.0^{\circ} \mathrm{E}$.

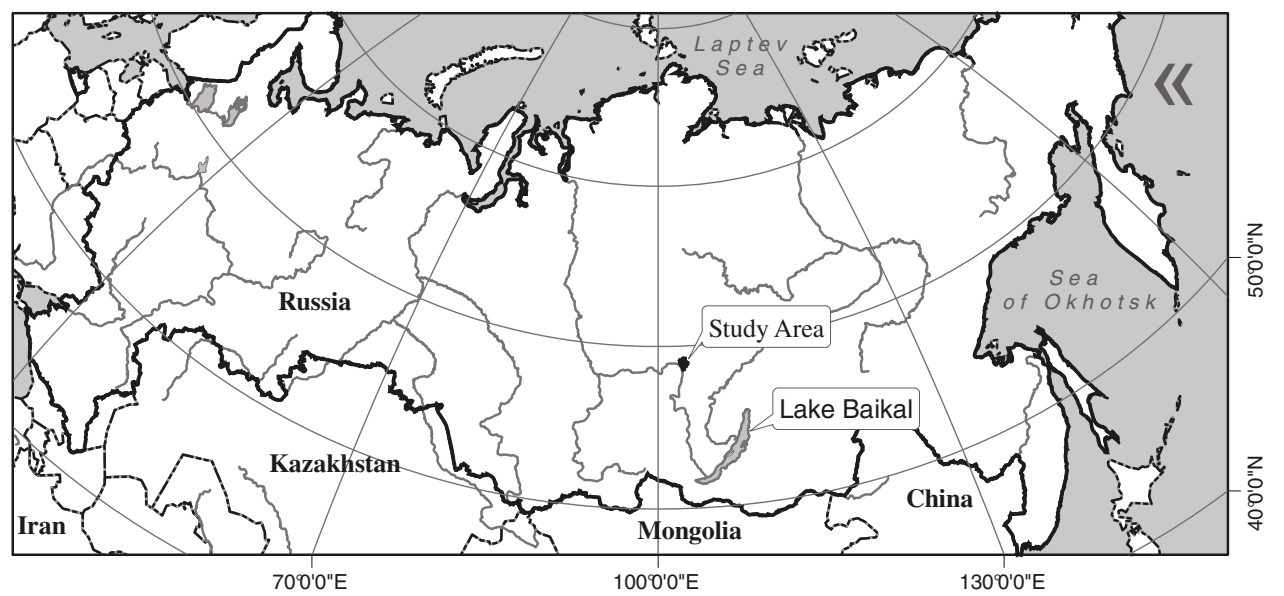

Table 1. Selected LANDIS biomass succession parameters reflecting future climate conditions for all major species of the study area. Probability of establishment $\left(P_{\text {est }}\right)$ and aboveground net primary productivity (ANPP) were derived from models as described in the text, and decay rates were obtained from the Russian ecological literature.

\begin{tabular}{llllll}
\hline & & & \multicolumn{2}{c}{ Decay rate $(k)^{a}$} \\
\cline { 5 - 6 } Species & Common name & $P_{\text {est }}$ & $\begin{array}{l}\text { Maximum ANPP } \\
(\mathrm{kg} / \text { ha/year })\end{array}$ & Woody & Leaf \\
\hline Picea obovata & Siberian spruce & 0.390 & 807 & 0.049 & 0.63 \\
Abies sibirica & Siberian fir & 0.198 & 688 & 0.053 & 0.63 \\
Larix sibirica & Siberian larch & 0.565 & 911 & 0.035 & 0.78 \\
Pinus sylvestris & Scots pine & 0.642 & 761 & 0.043 & 0.63 \\
Pinus sibirica & Russian kedar & 0.346 & 683 & 0.039 & 0.53 \\
Betula pendula & White birch & 0.519 & 862 & 0.060 & 1.00 \\
Populus tremula & Quaking aspen & 0.387 & 752 & 0.068 & 1.00 \\
\hline
\end{tabular}

${ }^{a} \operatorname{DeadBiomass}(t+1)=\operatorname{DeadBiomass}(t) \times \mathrm{e}^{-k}$.

dominated by relatively deep and fertile Sod-Podzols (Kolesnichenko et al. 1988). The study area is primarily a hilly plain ranging in elevation from 250 to $450 \mathrm{~m}$, with the Angara river valley located along the western edge. Forests of the region are dominated by Scots pine (Pinus sylvestris L.) and secondary soft-hardwood deciduous (birch (Betula pendula Roth), aspen (Populus tremula L.)) forests. Climate is continental, with long, severe winters (mean January temperature $=-29{ }^{\circ} \mathrm{C}$ ) and short, but warm (mean July temperature $=17{ }^{\circ} \mathrm{C}$ ) and humid summers (Vaschuk and Shvidenko 2006). Precipitation is $90 \mathrm{~cm}$ annually, with two-thirds falling from April to September (Vaschuk and Shvidenko 2006). Permafrost is rare in the study area, occurring only in small patches at the highest elevations. Mean temperature in the region rose $2-3.5{ }^{\circ} \mathrm{C}$ during the last century, with an accelerating rate of change, whereas precipitation did not change significantly (Vaschuk and Shvidenko 2006). An ensemble of GCMs predicted a temperature increase during the 21 st century for the region in the range of $4-6{ }^{\circ} \mathrm{C}$, with a lesser increase in precipitation (Meleshko et al. 2008).

Forest management in Siberia is currently not very sophisticated because boreal ecosystems are relatively simple (e.g., Table 1) and the logging equipment is not state-of-the-art. Russian foresters recognize two major forest ecosystems in boreal Russian Asia: dark and light coniferous forests. Dark conifers consist of the shade-tolerant Siberian spruce (Picea obovata Ledeb.), Siberian fir (Abies sibirica Ledeb.), and kedar. Because of their shade tolerance and longevity, dark conifers often develop into multiaged stands. Seed-tree cutting (clearcutting with residuals) is the dominant harvest method for dark conifers, although stands containing $>30 \%$ kedar (by volume) can be harvested only by selection cutting (Ministry of Natural Resources of the Russian Federation 2007b). Selection cutting has been shown to sustain dark conifer stands (Onuchin 2007), but it is not typically used except for reducing ecological impacts along rivers and on steep slopes. Light conifers are the fire-adapted Scots pine and Siberian larch (Larix sibirica Ledeb.). This type is usually found in even-aged stands that develop after highintensity fire, although recurrent non-stand-replacing surface fires often generate uneven-aged structure (e.g., Vaschuk and Shvidenko 2006). Scots pine is the most commercially valuable species, and light conifers are also harvested by seed-tree cutting. Aspen and birch are hardwood pioneer species that colonize stands of dark coniferous forest after stand-replacing disturbance such as fire or insect defoliation. They are less likely to colonize light coniferous stands after disturbance because pine and larch are also pioneer species (Vaschuk and Shvidenko 2006). Aspen and birch are not considered commercially valuable, although they are sometimes harvested when convenient. The age structure of these 
forests has been formed primarily by the fire regime, which is the dominant natural disturbance. The dark conifers are typically uneven-aged ( $>$ three age cohorts), usually succeeding the aspen-birch stands that establish following fire. Thirty percent of Scots pine and about $70 \%$ of mature larch stands (Vaschuk and Shvidenko 2006) are relatively unevenaged (two to three cohorts), a structure that develops when multiple surface fires kill ground vegetation and shrubs, allowing new cohorts to establish after each fire. All other stands are mostly even-aged, being established after standreplacing fire or harvest. Fires are mostly of human origin and most fires are not suppressed, so the size of fires can be quite large (>500 ha). Most (>90\%) fires are surface fires, but crown fires do occur (primarily in Scots pine stands) and are responsible for $17 \%$ of the total burned area (Vaschuk 1992; Vaschuk and Shvidenko 2006).

\section{Climate projections}

Future climate was estimated using an ensemble of four atmosphere-ocean GCMs running the A2 emissions scenario (IPCC 2007): Canadian Climate Centre (CCC) CCCma (McFarlane et al. 2005), General Fluid Dynamics Laboratory (GFDL) GFDL-CM2 (Delworth et al. 2006), Hadley HadCM3 (Gordon et al. 2000), and Max Planck Institute (MPI) MPI-echam5 (Giorgetta et al. 2006). To avoid calibration discrepancies between absolute model outputs and current climate, we calculated the change between monthly predictions of the present (1980-1999) and future (20802099) values of climate variables (temperature, precipitation, and photosynthetically active radiation (PAR)) within each model, averaged the change values of the four models, and used these averages to modify current monthly climate means as measured adjacent to the study area (city of Ust-Ilimsk weather station) during the period 1980-2001. Among the models, temperature increase between present and future ranged from $+1.2{ }^{\circ} \mathrm{C}$ (GFDL) to $+6.2(\mathrm{MPI})($ mean $=+4.2$ ), precipitation change ranged from $+15.4 \%$ (GFDL) to $+29.0 \%$ (CCC) $($ mean $=+20.4)$, and PAR change ranged from $-6.0 \%$ (GDFL) to $+0.7 \%$ (Hadley) (mean $=-3.1 \%$ ).

\section{The simulation model}

We simulated forest landscape dynamics using the processbased, spatially dynamic model of forest succession and disturbance LANDIS-II (Scheller et al. 2007a). When simulating novel conditions (e.g., climate change and novel disturbance regimes), process-based models are superior to models built on empirical relationships observed in the past (Gustafson et al. 2011). LANDIS-II represents the landscape as a grid of interacting cells, and each cell may contain multiple species and each species can be represented by one or many age cohorts. Each cohort will establish and respond to disturbance as a function of its life history attributes (e.g., shade tolerance) and, in the case of disturbance, its age. The primary model output is maps of forest conditions, including species, age classes, aboveground biomass (living and dead), and disturbance types and their respective severities. Spatial inputs for LANDIS-II take the form of raster maps $(100 \mathrm{~m}$ cell size in this study) and include ecoregions, tree species cohorts initially found on each cell, and timber harvest management areas. We used as input maps those generated for a previous study (Gustafson et al. 2010). The model and its in- puts were considered reliable by Gustafson et al. (2010) because (i) extensive testing and application of LANDIS-II model core assumptions and extensions had been completed in previous studies (Sturtevant et al. 2004), (ii) the behavior of all components under a current climate and disturbance (HRNV) scenario matches expert opinion about forest succession and disturbance dynamics in this part of Siberia, (iii) the proportions of species and age classes falls within observed ranges for the region under a simulated HRNV scenario, and (iv) sensitivity analysis showed that model behavior responds to input parameters as expected by the conceptual model(s) on which LANDIS-II was built.

We used six LANDIS-II extensions to simulate the ecological processes that determine the composition and landscape structure of the study area. Succession was simulated using Biomass Succession extension ver. 2 (Scheller and Mladenoff 2004). This extension calculates competition among cohorts, the increase of living biomass in cohorts of each tree species, and the gain and loss of woody and non-woody dead biomass using life history and physiological attributes (Table 1). Wind disturbance was simulated using Base Wind ver. 1.3 (Scheller et al. 2007b). This extension simulates cohort mortality caused by wind events, which kills older cohorts more readily than younger ones. Tree cohort mortality caused by the Siberian silk moth was simulated using the Base BDA (biological disturbance agent) extension ver. 1.1 (Sturtevant et al. 2004). Fires were simulated using the Dynamic Fire System extension ver. 1.0 (Sturtevant et al. 2009). This extension simulates fire severity and spread based on previous LANDIS fire modules (e.g., Yang et al. 2004) and the Canadian Forest Fire Behavior Prediction System (Forestry Canada Fire Danger Group 1992) and the resulting cohort mortality. Fire events are initiated probabilistically (Yang et al. 2004), and fire weather characterized by the Canadian Forest Fire Weather Index System (Van Wagner 1987) is randomly selected from historic daily weather records. Fuel types as required by the fire extension were calculated by the Dynamic Fuels System extension ver. 1.0 (Sturtevant et al. 2009). This extension translates LANDIS-II speciescohort (and logging history) information into Canadian Fire Behavior Prediction System fuel types (Forestry Canada Fire Danger Group 1992). Timber harvesting was simulated using the Biomass Harvest extension ver. 1.3 (Gustafson et al. 2000). This extension simulates removal of cohort biomass (including partial biomass of individual cohorts) caused by timber harvest activities and links to the fuel extension to account for logging history (e.g, production of slash). We specified rules for partial removal of cohort biomass to approximate the more precise practice of selection cutting. Each process was simulated using a 10-year time step. All LANDIS-II parameters were set according to Gustafson et al. (2010) (http://www.esapubs.org/archive/appl/ A020/021/), except the timber harvest parameters, which were varied as experimental treatments, and the climate parameters (see below). During simulation runs, climate parameters were modified from current toward future (20802099) values in years 40,70 , and 100 using interpolated parameter values. Parameters remained unchanged after year 100 because that is the temporal limit of IPCC climate projections and we had no defensible basis to determine when climate may cease to change. Although climate may 
Table 2. Species life history parameters used to calculate probability of establishment $\left(P_{\text {est }}\right)$. Table parameter values were derived from the ecological literature.

\begin{tabular}{|c|c|c|c|c|c|}
\hline \multirow[b]{2}{*}{ Species } & \multirow{2}{*}{ 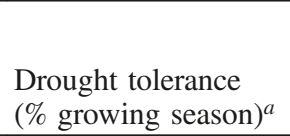 } & \multicolumn{2}{|l|}{$\mathrm{GDD}^{b}$} & \multirow{2}{*}{$\begin{array}{l}\text { Minimum January } \\
\text { temperature }\left({ }^{\circ} \mathrm{C}\right)\end{array}$} & \multirow{2}{*}{$\begin{array}{l}\text { Ability to tolerate } \\
\text { low nitrogen }\end{array}$} \\
\hline & & Minimum & Maximum & & \\
\hline Picea obovata & 25 & 750 & 2500 & -58 & Medium \\
\hline Abies sibirica & 16 & 950 & 2500 & -55 & Low \\
\hline Larix sibirica & 33 & 670 & 3000 & -66 & High \\
\hline Pinus sylvestris & 38 & 730 & 3100 & -55 & High \\
\hline Pinus sibirica & 23 & 700 & 2300 & -58 & Medium \\
\hline Betula pendula & 31 & 700 & 3200 & -59 & Medium \\
\hline Populus tremula & 25 & 900 & 3000 & -45 & Medium \\
\hline
\end{tabular}

Note: Mean soil parameters for the study area: field capacity $=19 \mathrm{~cm}$; wilting point $=8.75 \mathrm{~cm}$ (V. Rozhkov, personal communication); base soil $\mathrm{N}=11.0 \mathrm{Mg} / \mathrm{ha}$ (Shvidenko et al. 2005).

${ }^{a}$ Maximum length of drought that can be tolerated by the species.

${ }^{b}$ Minimum and maximum bounds for a temperature envelope defined by growing degree days $\left(\right.$ GDD; base $\left.=5{ }^{\circ} \mathrm{C}\right)$.

continue to change, our assumption allowed us to evaluate the likely long-term effects of timber management strategies under the expected climate conditions of the next century.

The Biomass Succession extension uses estimates of the maximum possible aboveground net primary productivity (ANPP) for each species to simulate growth and succession processes, and ANPP is expected to vary with climate. Because future ANPP cannot be measured empirically, we modeled ANPP using the forest carbon and water balance model PnET-II ver. 4.1-1.2c (Aber et al. 1995) to generate comparable ANPP values for both current and future climates. PnETII predictions for ANPP under current climate matched empirical observations within $4 \%$ (Gustafson et al. 2010). Future ANPP was predicted by modifying the PnET input parameters of monthly means of surface temperature, precipitation, and PAR as predicted by the GCMs. The probability of establishment $\left(P_{\text {est }}\right)$ for each species is also expected to vary with climate, and these were estimated using a simulation approach (Gustafson et al. 2010). To estimate $P_{\text {est }}, 300$ weather years were stochastically generated using the means and standard deviations of temperature and precipitation and compared with species vital attributes (drought tolerance, preferred climate, cold tolerance, and soil nitrogen tolerance) and other abiotic characteristics, including soil field capacity, wilting point, and available nitrogen (Table 2), with estimates of $P_{\text {est }}$ being proportional to survival and growth under the simulated weather conditions. Establishment is also limited by available light at the forest floor in conjunction with species shade tolerance (Scheller et al. 2007a) and the availability of propagules, a distance-weighted probability (Scheller and Mladenoff 2004). Forest floor conditions (e.g., duff thickness) and their effect on establishment are not explicitly simulated, although fire triggers serotinous seeding and additional aerial seeding (Scheller et al. 2007a), mimicking the effects of fire in creating an appropriate seedbed. We did not include in-migration of other species because (i) no other species are found within $300 \mathrm{~km}$ of our study area, (ii) unforested steppes occur further to the south, and (iii) actual range shifts in this area are exceedingly slow (Udra 1990).

The fire regime is also likely to respond to changing climate, and our approach was to allow the process-based fire extension to respond to projected future weather, rather than try to guess what the future fire regime might be. Fire regimes in the fire extension were specified by an ignition rate and a fire-duration distribution. Although temperatures are projected to increase in the study area, future precipitation is not expected to decrease and drought occurrence is not projected to change significantly (Malevsky-Malevich et al. 2008). We therefore assumed that the length of time between fire-extinguishing rain events would not increase compared with current conditions, and we used the current distribution of fire durations. However, with warmer temperatures, simulated fuels will be drier and fires will tend to be larger and more severe for a given fire duration. Also, because warmer climate will result in a longer fire season and a higher ignition rate, the mean number of fires per year was increased by $10 \%$ over the current number. Fire parameters were estimated using a combination of official fire occurrence data, remote sensing, and expert knowledge of the fire regime, taking into account that official statistics under-report fire events by up to an order of magnitude in the study area (Vaschuk 1992; Baltzer et al. 2004; Vaschuk and Shvidenko 2006). The weather associated with each fire was selected from a weather stream according to season (e.g., spring leaf-off, summer leaf-on). To produce a weather stream under future climate, we used the historic daily weather record (1980 2001) from the nearest city (Ust-Ilimsk) and modified each temperature and precipitation record by the average change projected for the month by the ensemble of GCMs.

We evaluated the sensitivity of our results to the assumption that fire duration will be unchanged in the future by varying the mean fire duration $\pm 10 \%$ and found that although this parameter does have a significant effect on some response variables (as one would expect), the effect was generally not extremely high or ubiquitous among response variables. For example, fire severity and area burned were not significantly affected, but the biomass of some fire-intolerant species and the oldest and youngest age classes were affected. Area disturbed by insects was also significantly affected because of the effect on host species, but not enough to also affect fire intensity or area burned. Most response variables were either marginally affected or not significantly affected. We concluded that our results were not particularly sensitive to our fire-duration assumption. 


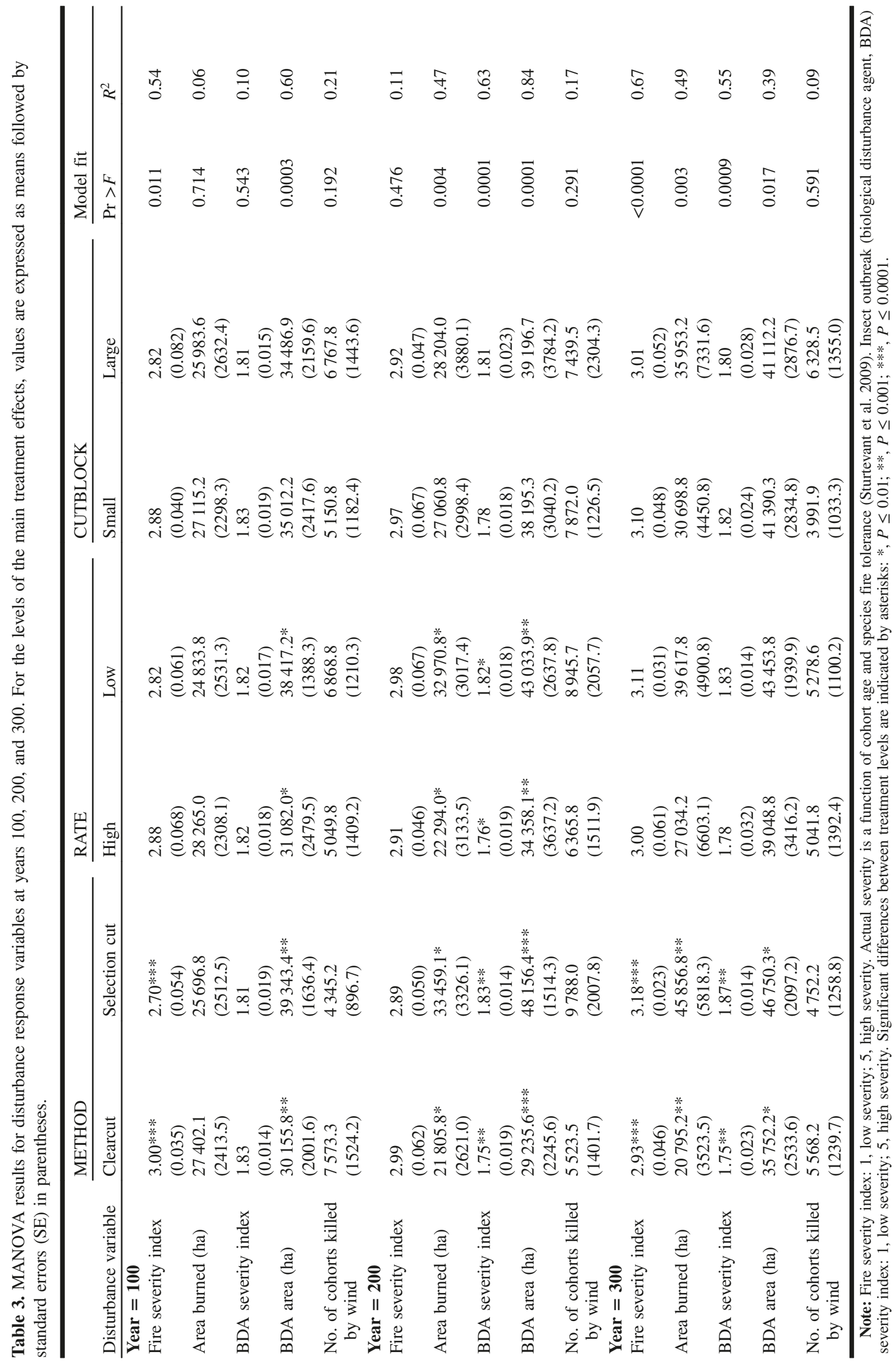


Fig. 2. Area disturbed over time by $(a)$ fire and $(b)$ silk moth. Error bars show one standard deviation from the mean. Breaks between points indicate no disturbed area during the decade.
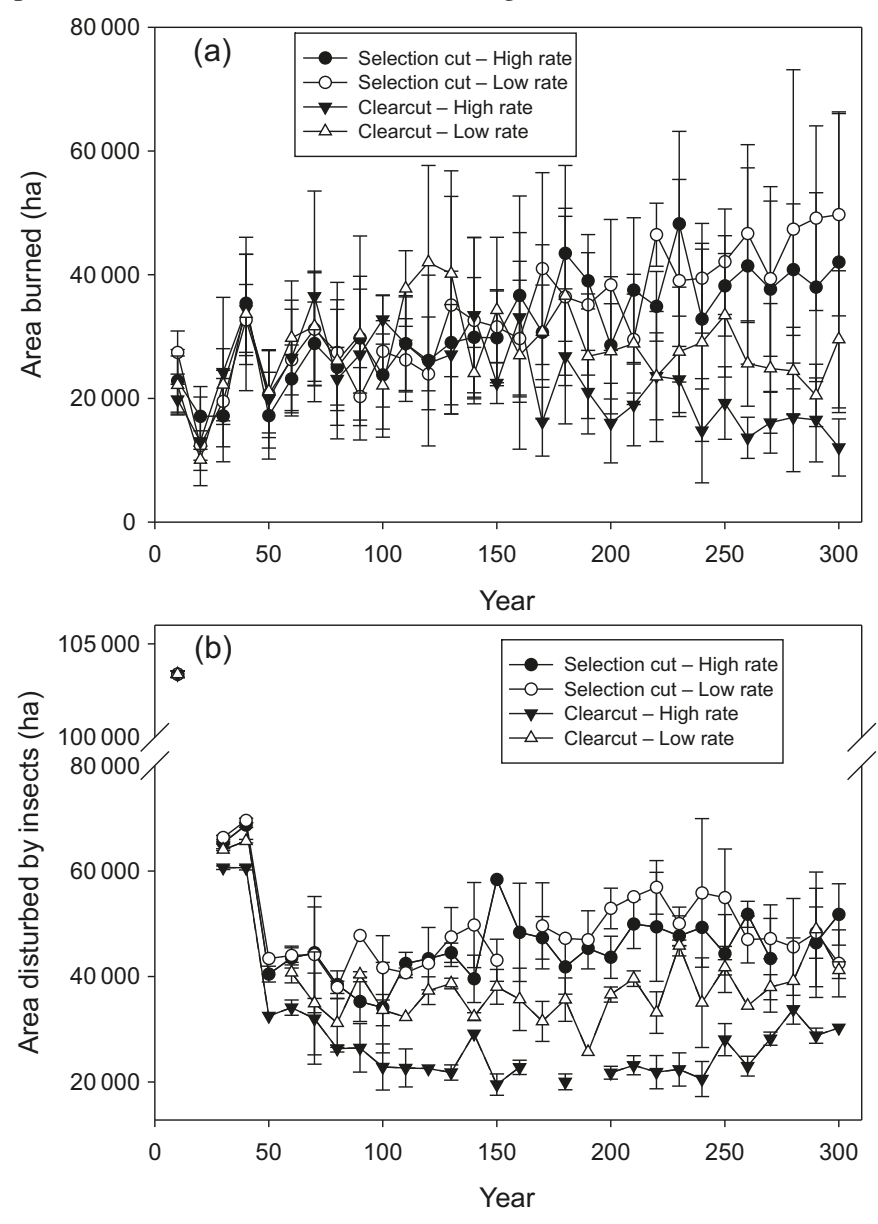

\section{Treatments}

The treatments were applied by varying parameters of the harvest extension. (1) The METHOD treatment had two levels (clearcut and selection cut). The clearcut harvest treatment removed all cohorts for both conifers and hardwoods. The selection-cut treatment also clearcut hardwood stands (necessary for regeneration), but for conifer stands, a specified proportion of biomass was removed from existing cohorts, depending on cohort age: $10 \%$ of the biomass was removed from any conifer cohorts that were between $25 \%$ and $40 \%$ of the species' longevity, 25\% from cohorts between $40 \%$ and $55 \%$ of longevity, $50 \%$ of cohorts between $55 \%$ and $70 \%$ of longevity, $75 \%$ of cohorts between $70 \%$ and $85 \%$ of longevity, and $100 \%$ of cohorts $>85 \%$ of longevity. For hardwood cohorts occurring within selection-cut stands, $50 \%$ of the biomass was removed from cohorts between 30 and 49 years old and $100 \%$ was removed from $>50$-year-old cohorts. Stands were defined as hardwood if the oldest cohort on the majority of cells was a hardwood species, and conifer, otherwise. The minimum age for selecting stands for cutting was 50 years for hardwoods and 100 years for conifers. (2) Cutting RATE was specified by setting the total harvested area parameter (levels: $2.5 \%$ and $5.0 \%$ of the study area per decade), allocating the target cutting rate among the two forest types in proportion to their abundance in the initial condi- tions map. (3) CUTBLOCK size ( $s$; levels: 25 and 100 ha) was controlled by allowing cutblocks to expand cell by cell across stand boundaries as needed to achieve a target size of $s$ (ha), with no cutblocks smaller than $s-5$ permitted. Adjacency constraints were enforced to ensure that cutblock size was precisely controlled (i.e., all adjacent stands must be at least 10 years old for a stand to be cut). For all treatments, stands were selected for harvest in decreasing order of age.

\section{Analysis}

Treatment effects were calculated using multivariate analysis of variance (MANOVA) models using SAS ver. 9.2 (SAS Institute Inc. 2008), which allow for global hypothesis tests of factor effects for multiple dependent variables (Johnson and Wichern 1992). Separate analyses were conducted for each of the six categories of response variables (susceptibility to disturbance, species composition, age-class composition, spatial pattern, aboveground live biomass, and biomass harvested). Within each analysis, a subset of representative response variables was chosen to reduce multicollinearity (see Results). Because response variables varied through time, we chose simulation years 100,200 , and 300 as representative of the varying response. The MANOVA models used the error sums of squares and cross-products (residual) matrix, and the results were evaluated using type I sums of squares. The relative influence of each main effect was quantified as the significance of the difference in means of the response variables. Significance was judged conservatively using $\alpha=0.01$ because random noise was minimal in this tightly controlled simulation experiment.

Using the results from the experiment, we generated a "recommended" strategy that could be expected to mitigate cohort losses to disturbance, maintain forest composition within the HRNV, favor species that are better adapted to future conditions, and reduce forest fragmentation. The HRNV was estimated by Gustafson et al. (2010) by simulating three replicates of current climate, current wind, and fire regimes for 200 years (timber harvest and insect outbreaks were excluded). We assumed that the species best adapted to future conditions were those with increased ANPP and $P_{\text {est }}$ under future conditions as compared with current conditions (Gustafson et al. 2010; Table 1). We compared the results of this "recommended" strategy with those of a "business-as-usual" strategy (clearcutting at a high rate with 40 ha cutblocks), where the current management strategy is continued indefinitely.

\section{Results}

The response to the treatments was most dramatic in the first 100 years, as the experimental harvest regimes modified the previously unharvested initial conditions. The trends of the first 100 years were not reversed in subsequent years with the following exceptions. The abundance of larch initially increased under a selection-cut method but began to gradually decline thereafter. The abundance of the oldest age class initially increased under the selection-cut method but began to decline after year 150. Similarly, the abundance of the youngest age class initially increased under the clearcut method but began to decline after year 150. These trend reversals were likely caused by interactions of the treatments 
Table 4. MANOVA results for species composition variables at years 100, 200, and 300. For the levels of the main treatment effects, values are expressed as means followed by standard errors (SE) in parentheses.

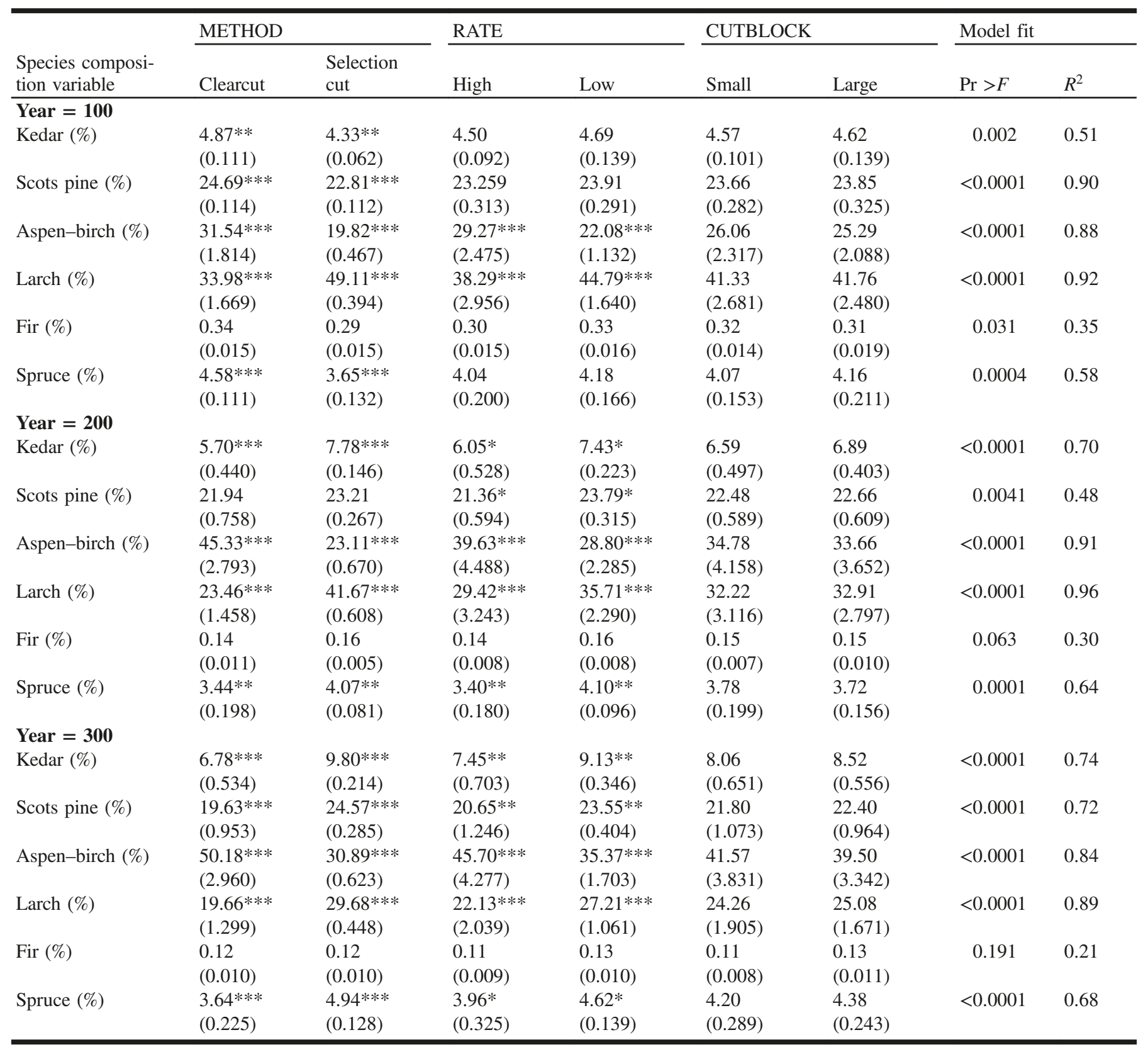

Note: Significant differences between treatment levels are indicated by asterisks: *, $P \leq 0.01$; **, $P \leq 0.001$; **, $P \leq 0.0001$.

with natural disturbances. Also, in general, there was sometimes a significant interaction between the METHOD and RATE treatments, caused by the fact that when a METHOD treatment has a significant effect, the area treated by the METHOD will change as a function of RATE, multiplying the effect of the METHOD. These interactions are not shown.

\section{Disturbance response variables}

The susceptibility of the landscape to disturbance was mostly affected by the METHOD treatment, but the RATE treatment also had an effect, mostly on insect disturbance (Table 3). Clearcutting reduced the average age of the forest more than selection cutting and tended to increase the abun- dance of broad-leaved species, both of which resulted in reduced susceptibility to fire and insects (Fig. 2). Although reduced age should have reduced susceptibility to windthrow, the response of "cohorts killed by wind" was not significant. The RATE treatment significantly reduced the area of insect outbreaks in the first 200 years, presumably by increasing the abundance of deciduous species and reducing the mean forest age on more of the landscape.

\section{Composition response variables}

METHOD and RATE treatments generally had a very significant effect on the species composition of the landscape, whereas CUTBLOCK treatment generally was not significant (Table 4). Clearcutting favored birch and aspen at the ex- 
Table 5. MANOVA results for age-class composition response variables at years 100, 200, and 300. For the levels of the main treatment effects, values are expressed as means followed by standard errors (SE) in parentheses.

\begin{tabular}{|c|c|c|c|c|c|c|c|c|}
\hline \multirow[b]{2}{*}{$\begin{array}{l}\text { Age-class compo- } \\
\text { sition variable }\end{array}$} & \multicolumn{2}{|c|}{ METHOD } & \multicolumn{2}{|l|}{ RATE } & \multicolumn{2}{|c|}{ CUTBLOCK } & \multicolumn{2}{|l|}{ Model fit } \\
\hline & Clearcut & $\begin{array}{l}\text { Selection } \\
\text { cut }\end{array}$ & High & Low & Small & Large & $\operatorname{Pr}>F$ & $R^{2}$ \\
\hline \multicolumn{9}{|l|}{ Year $=100$} \\
\hline $1-40$ year $(\%)$ & $\begin{array}{l}34.6^{* * * *} \\
(1.99)\end{array}$ & $\begin{array}{l}17.8^{* * * *} \\
(0.61)\end{array}$ & $\begin{array}{l}29.9 * * * \\
(3.33)\end{array}$ & $\begin{array}{l}22.5 * * * \\
(1.89)\end{array}$ & $\begin{array}{l}26.5 \\
(2.82)\end{array}$ & $\begin{array}{l}26.0 \\
(3.043)\end{array}$ & $<0.0001$ & 0.89 \\
\hline $41-100$ year $(\%)$ & $\begin{array}{l}18.5^{* * *} \\
(0.72)\end{array}$ & $\begin{array}{l}14.1 * * * \\
(0.32)\end{array}$ & $\begin{array}{l}17.3 * * \\
(0.94)\end{array}$ & $\begin{array}{l}15.2 * * \\
(0.66)\end{array}$ & $\begin{array}{l}15.9 \\
(0.68)\end{array}$ & $\begin{array}{l}16.6 \\
(1.01)\end{array}$ & $<0.0001$ & 0.74 \\
\hline $101-140$ year $(\%)$ & $\begin{array}{l}8.4 \\
(0.14)\end{array}$ & $\begin{array}{l}8.6 \\
(0.10)\end{array}$ & $\begin{array}{l}8.3^{*} \\
(0.12)\end{array}$ & $\begin{array}{l}8.7^{*} \\
(0.10)\end{array}$ & $\begin{array}{l}8.5 \\
(0.14)\end{array}$ & $\begin{array}{l}8.5 \\
(0.11)\end{array}$ & 0.045 & 0.32 \\
\hline $141-180$ year $(\%)$ & $\begin{array}{l}12.7 * * * \\
(0.35)\end{array}$ & $\begin{array}{l}14.2 * * * \\
(0.12)\end{array}$ & $\begin{array}{l}12.8 * * * \\
(0.37)\end{array}$ & $\begin{array}{l}14.1 * * * \\
(0.14)\end{array}$ & $\begin{array}{l}13.5 \\
(0.34)\end{array}$ & $\begin{array}{l}13.3 \\
(0.34)\end{array}$ & $<0.0001$ & 0.76 \\
\hline$>180$ year $(\%)$ & $\begin{array}{l}25.7 * * * \\
(2.00)\end{array}$ & $\begin{array}{l}45.3^{* * *} \\
(0.51)\end{array}$ & $\begin{array}{l}31.7 * * * \\
(3.78)\end{array}$ & $\begin{array}{l}39.4 * * * \\
(2.18)\end{array}$ & $\begin{array}{l}35.5 \\
(3.08)\end{array}$ & $\begin{array}{l}35.5 \\
(3.50)\end{array}$ & $<0.0001$ & 0.93 \\
\hline \multicolumn{9}{|l|}{ Year $=200$} \\
\hline $1-40$ year $(\%)$ & $\begin{array}{l}35.5 * * * \\
(1.32)\end{array}$ & $\begin{array}{l}24.9 * * * \\
(0.83)\end{array}$ & $\begin{array}{l}32.8 * * \\
(2.13)\end{array}$ & $\begin{array}{l}27.7^{* *} \\
(1.38)\end{array}$ & $\begin{array}{l}29.8 \\
(1.92)\end{array}$ & $\begin{array}{l}30.6 \\
(1.96)\end{array}$ & $<0.0001$ & 0.84 \\
\hline $41-100$ year $(\%)$ & $\begin{array}{l}25.7 * * * \\
(1.30)\end{array}$ & $\begin{array}{l}13.4 * * * \\
(0.53)\end{array}$ & $\begin{array}{l}21.4 * * \\
(2.47)\end{array}$ & $\begin{array}{l}17.7 * * \\
(1.48)\end{array}$ & $\begin{array}{l}19.6 \\
(1.91)\end{array}$ & $\begin{array}{l}19.5 \\
(2.30)\end{array}$ & $<0.0001$ & 0.85 \\
\hline $101-140$ year $(\%)$ & $\begin{array}{l}12.5 \\
(0.31)\end{array}$ & $\begin{array}{l}12.0 \\
(0.37)\end{array}$ & $\begin{array}{l}12.3 \\
(0.32)\end{array}$ & $\begin{array}{l}12.1 \\
(0.37)\end{array}$ & $\begin{array}{l}12.2 \\
(0.33)\end{array}$ & $\begin{array}{l}12.2 \\
(0.36)\end{array}$ & 0.743 & 0.60 \\
\hline $141-180$ year $(\%)$ & $\begin{array}{l}9.3 * * \\
(0.79)\end{array}$ & $\begin{array}{l}12.3 * * \\
(0.25)\end{array}$ & $\begin{array}{l}9.5^{* *} \\
(0.85)\end{array}$ & $\begin{array}{l}12.0 * * \\
(0.29)\end{array}$ & $\begin{array}{l}11.0 \\
(0.73)\end{array}$ & $\begin{array}{l}10.6 \\
(0.75)\end{array}$ & $<0.0001$ & 0.64 \\
\hline$>180$ year $(\%)$ & $\begin{array}{l}17.0^{* * * *} \\
(1.42)\end{array}$ & $\begin{array}{l}37.4 * * * \\
(0.79)\end{array}$ & $\begin{array}{l}24.0 * * * \\
(3.52)\end{array}$ & $\begin{array}{l}30.4 * * * \\
(2.72)\end{array}$ & $\begin{array}{l}27.4 \\
(3.11)\end{array}$ & $\begin{array}{l}26.9 \\
(3.47)\end{array}$ & $<0.0001$ & 0.97 \\
\hline \multicolumn{9}{|l|}{ Year $=300$} \\
\hline $1-40$ year $(\%)$ & $\begin{array}{l}31.3 \\
(0.90)\end{array}$ & $\begin{array}{l}33.5 \\
(1.17)\end{array}$ & $\begin{array}{l}33.2 \\
(1.02)\end{array}$ & $\begin{array}{l}31.6 \\
(1.12)\end{array}$ & $\begin{array}{l}32.5 \\
(1.00)\end{array}$ & $\begin{array}{l}32.3 \\
(1.18)\end{array}$ & 0.388 & 0.13 \\
\hline $41-100$ year $(\%)$ & $\begin{array}{l}27.5^{* * * *} \\
(1.08)\end{array}$ & $\begin{array}{l}18.4 * * * \\
(0.75)\end{array}$ & $\begin{array}{l}25.1 * * \\
(1.79)\end{array}$ & $\begin{array}{l}20.8 * * \\
(1.24)\end{array}$ & $\begin{array}{l}22.3 \\
(1.67)\end{array}$ & $\begin{array}{l}23.6 \\
(1.65)\end{array}$ & $<0.0001$ & 0.84 \\
\hline $101-140$ year $(\%)$ & $\begin{array}{l}15.6^{*} \\
(0.56)\end{array}$ & $\begin{array}{l}13.4 * \\
(0.46)\end{array}$ & $\begin{array}{l}15.0 \\
(0.65)\end{array}$ & $\begin{array}{l}14.0 \\
(0.52)\end{array}$ & $\begin{array}{l}14.2 \\
(0.39)\end{array}$ & $\begin{array}{l}14.8 \\
(0.76)\end{array}$ & 0.020 & 0.38 \\
\hline $141-180$ year $(\%)$ & $\begin{array}{l}11.5 \\
(0.84)\end{array}$ & $\begin{array}{l}11.2 \\
(0.56)\end{array}$ & $\begin{array}{l}10.0^{*} \\
(0.54)\end{array}$ & $\begin{array}{l}12.7^{*} \\
(0.65)\end{array}$ & $\begin{array}{l}11.7 \\
(0.75)\end{array}$ & $\begin{array}{l}11.0 \\
(0.68)\end{array}$ & 0.034 & 0.34 \\
\hline$>180$ year $(\%)$ & $\begin{array}{l}14.0 * * * \\
(1.08)\end{array}$ & $\begin{array}{l}24.5 * * * \\
(0.68)\end{array}$ & $\begin{array}{l}16.7 * * \\
(1.88)\end{array}$ & $\begin{array}{l}20.8^{* *} \\
(1.18)\end{array}$ & $\begin{array}{l}19.3 \\
(1.54)\end{array}$ & $\begin{array}{l}18.3 \\
(1.81)\end{array}$ & $<0.0001$ & 0.86 \\
\hline
\end{tabular}

Note: Significant differences between treatment levels are indicated by asterisks: *, $P \leq 0.01$; **, $P \leq 0.001$; ***, $P \leq 0.0001$.

pense of the other species, particularly larch, compared with selection cutting. Increasing the area harvested also favored birch and aspen at the expense of the other species, again with larch particularly affected. The age-class composition was also generally significantly affected by the METHOD and RATE treatments, but not the CUTBLOCK treatment (Table 5). Clearcutting produced more young age classes at the expense of the oldest age classes compared with selection cutting, and as the area cut increased, the average age of stands decreased, regardless of the METHOD used. The amount of forest in the middle age classes was often not significantly different among treatment levels, with the treatment affecting primarily the youngest and oldest age classes. The significance of the METHOD treatment on age classes declined through time because the proportion of the oldest and youngest age classes tended to increase under selection cutting and decrease under clearcutting, converging at about year 300. Similarly, the effect of RATE was greatest initially because the high cutting rate produced a large change from the initial conditions.

\section{Spatial pattern response variables}

The aggregation index (AI) is proportional to the number of edges shared by pixels of the same class (He et al. 2000), and it was significantly affected by the METHOD and RATE treatments in years 100 and 300 but not in year 200 (Table 6). AI was not affected by the CUTBLOCK treatment. GISfrag (Ripple et al. 1991) is the mean distance of a forested site from the nearest edge or opening, and it reflected fragmentation primarily by young forest openings in this heavily forested landscape. GISfrag was significantly affected by the METHOD and CUTBLOCK treatments in years 100 and 200 and by the RATE treatment in year 100. The effects appeared to erode through time, presumably because the differences in the abundance of the youngest age class between levels of the treatments disappeared by year 300 (see Table 5).

\section{Biomass response variables}

The residual biomass of most species was significantly affected by the METHOD and RATE treatments, but not by the 
Table 6. MANOVA results for spatial pattern response variables at years 100, 200, and 300. For the levels of the main treatment effects, values are expressed as means followed by standard errors (SE) in parentheses.

\begin{tabular}{|c|c|c|c|c|c|c|c|c|}
\hline \multirow[b]{2}{*}{$\begin{array}{l}\text { Spatial pattern } \\
\text { variable }\end{array}$} & \multicolumn{2}{|l|}{ METHOD } & \multicolumn{2}{|l|}{ RATE } & \multicolumn{2}{|c|}{ CUTBLOCK } & \multicolumn{2}{|l|}{ Model fit } \\
\hline & Clearcut & $\begin{array}{l}\text { Selection } \\
\text { cut }\end{array}$ & High & Low & Small & Large & $\operatorname{Pr}>F$ & $R^{2}$ \\
\hline \multicolumn{9}{|l|}{ Year $=100$} \\
\hline AI by species & $\begin{array}{l}0.29 * * * \\
(0.004)\end{array}$ & $\begin{array}{l}0.34 * * * \\
(0.002)\end{array}$ & $\begin{array}{l}0.30^{* * * *} \\
(0.009)\end{array}$ & $\begin{array}{l}0.32 * * * \\
(0.006)\end{array}$ & $\begin{array}{l}0.31 \\
(0.008)\end{array}$ & $\begin{array}{l}0.32 \\
(0.009)\end{array}$ & $<0.0001$ & 0.94 \\
\hline GISfrag (m) & $\begin{array}{l}377.9 * * * \\
(17.42)\end{array}$ & $\begin{array}{l}569.4 * * * \\
(15.98)\end{array}$ & $\begin{array}{l}438.4^{* *} \\
(34.45)\end{array}$ & $\begin{array}{l}509.0 * * \\
(28.48)\end{array}$ & $\begin{array}{l}442.5 * * * \\
(29.46)\end{array}$ & $\begin{array}{l}504.8 * * * \\
(34.36)\end{array}$ & $<0.0001$ & 0.93 \\
\hline \multicolumn{9}{|l|}{ Year $=200$} \\
\hline AI by species & $\begin{array}{l}0.22 * * * \\
(0.003)\end{array}$ & $\begin{array}{l}0.24 * * * \\
(0.002)\end{array}$ & $\begin{array}{l}0.24 \\
(0.002)\end{array}$ & $\begin{array}{l}0.23 \\
(0.005)\end{array}$ & $\begin{array}{l}0.23 \\
(0.004)\end{array}$ & $\begin{array}{l}0.24 \\
(0.004)\end{array}$ & $<0.0001$ & 0.69 \\
\hline GISfrag (m) & $\begin{array}{l}370.8 * * * \\
(13.67)\end{array}$ & $\begin{array}{l}450.3 * * * \\
(15.18)\end{array}$ & $\begin{array}{l}398.4 \\
(19.33)\end{array}$ & $\begin{array}{l}422.6 \\
(17.44)\end{array}$ & $\begin{array}{l}389.8 * \\
(19.67)\end{array}$ & $\begin{array}{l}431.3^{*} \\
(15.47)\end{array}$ & 0.0008 & 0.56 \\
\hline \multicolumn{9}{|l|}{ Year $=300$} \\
\hline AI by species & $\begin{array}{l}0.21 * * * \\
(0.006)\end{array}$ & $\begin{array}{l}0.18^{* * * *} \\
(0.001)\end{array}$ & $\begin{array}{l}0.20^{*} \\
(0.008)\end{array}$ & $\begin{array}{l}0.18^{*} \\
(0.002)\end{array}$ & $\begin{array}{l}0.19 \\
(0.005)\end{array}$ & $\begin{array}{l}0.20 \\
(0.007)\end{array}$ & $<0.0001$ & 0.47 \\
\hline GISfrag (m) & $\begin{array}{l}380.9 \\
(15.25)\end{array}$ & $\begin{array}{l}365.4 \\
(13.25)\end{array}$ & $\begin{array}{l}370.9 \\
(15.43)\end{array}$ & $\begin{array}{l}375.5 \\
(13.42)\end{array}$ & $\begin{array}{l}346.9 \\
(11.98)\end{array}$ & $\begin{array}{l}399.5 \\
(12.24)\end{array}$ & 0.043 & 0.33 \\
\hline
\end{tabular}

Note: Significant differences between treatment levels are indicated by asterisks: $*, P \leq 0.01 ; * *, P \leq 0.001 ; * * *, P \leq 0.0001$. AI by species is the aggregation index (0-1) for the species maps. AI is proportional to the number of edges shared by pixels of the same class (He et al. 2000). GISfrag is the mean distance of a forested site from the nearest edge or opening (Ripple et al. 1991).

CUTBLOCK treatment (Table 7). Aspen and birch biomass was higher under clearcutting than selection cutting and increased as more area was cut, whereas all other species had reduced biomass under clearcutting and as the area cut increased. Scots pine biomass did not respond significantly to the METHOD treatment, and spruce and fir did not respond in year 300. Pine, spruce, and fir biomass tended not to respond to the RATE treatment. The total residual biomass (all species combined) was not consistently affected by the treatments. Clearcutting initially reduced residual biomass, but by year 300, the residual biomass was slightly higher on landscapes managed by clearcutting (Table 7; Fig. 3).

\section{Biomass harvested response variable}

The treatments produced differences in the biomass extracted by harvesting (Fig. 3). Clearcutting removed approximately three times as much biomass as selection cutting (Table 8), the "low" RATE treatment (2.5\% of the landscape cut) produced about half of the biomass extracted as the "high" level (5.0\%), and the CUTBLOCK treatment had no effect.

\section{Recommended strategy compared with business-as-usual strategy}

Because clearcutting reduced losses to disturbance and selection cutting increased the abundance of species best adapted to future conditions (see Gustafson et al. 2010), the recommended strategy was to remove half of the timber by clearcutting and half by selection cutting. Because high rates of cutting reduced the abundance of species best adapted to future conditions and increased fragmentation, the harvest rate under the recommended alternative was intermediate between the treatment levels (i.e., 3.75\%). The recommended cutblock size was "large" (100 ha) because it reduced fragmentation and had little effect on other forest characteristics. When we compared this recommended scenario with the business-as-usual scenario, we found that the recommended strategy produced forest composition (species and age classes) values that were more evenly distributed and closer to the HRNV than the business-as-usual strategy (Table 9). Furthermore, the abundance and biomass of species that are expected to be best adapted to future conditions (pine, spruce, aspen, and birch) were generally significantly higher under the recommended strategy (Fig. 4). However, the recommended strategy failed to produce significant reductions in the disturbances of fire, insects, and wind (not shown), and in the case of insects, the recommended strategy was significantly worse. The recommended strategy did produce more forest interior habitat (forest $>300 \mathrm{~m}$ from an opening or edge), but the AI values (by species and by age class) were lower, so the effect on fragmentation was somewhat mixed. The recommended strategy left more residual living biomass on the landscape.

\section{Discussion}

Our results provide valuable insights into the potential for management strategies to mitigate global change effects in Siberia, but there are a number of important uncertainties that should be kept in mind. First, there is uncertainty in the projections of future climate (IPCC 2007). However, in a study that estimated the relative influence of climate, timber harvesting, and insect outbreaks on forest dynamics in the study area, Gustafson et al. (2010) found that the sensitivity of forest dynamics to climate was much less than to harvesting or insects. There is also uncertainty in many of the LANDIS-II parameter estimates. The amount of uncertainty varies among parameters, and the sensitivity of the results also varies among parameters. The uncertainty associated with the succession parameters is relatively low because $\mathrm{Si}$ berian forests are relatively well studied. Uncertainty in the disturbance parameters of wind and fire stems mostly from 
Table 7. MANOVA results for species aboveground living biomass response variables across the entire study area at years 100, 200, and 300. For the levels of the main treatment effects, values are expressed as means followed by standard errors (SE) in parentheses.

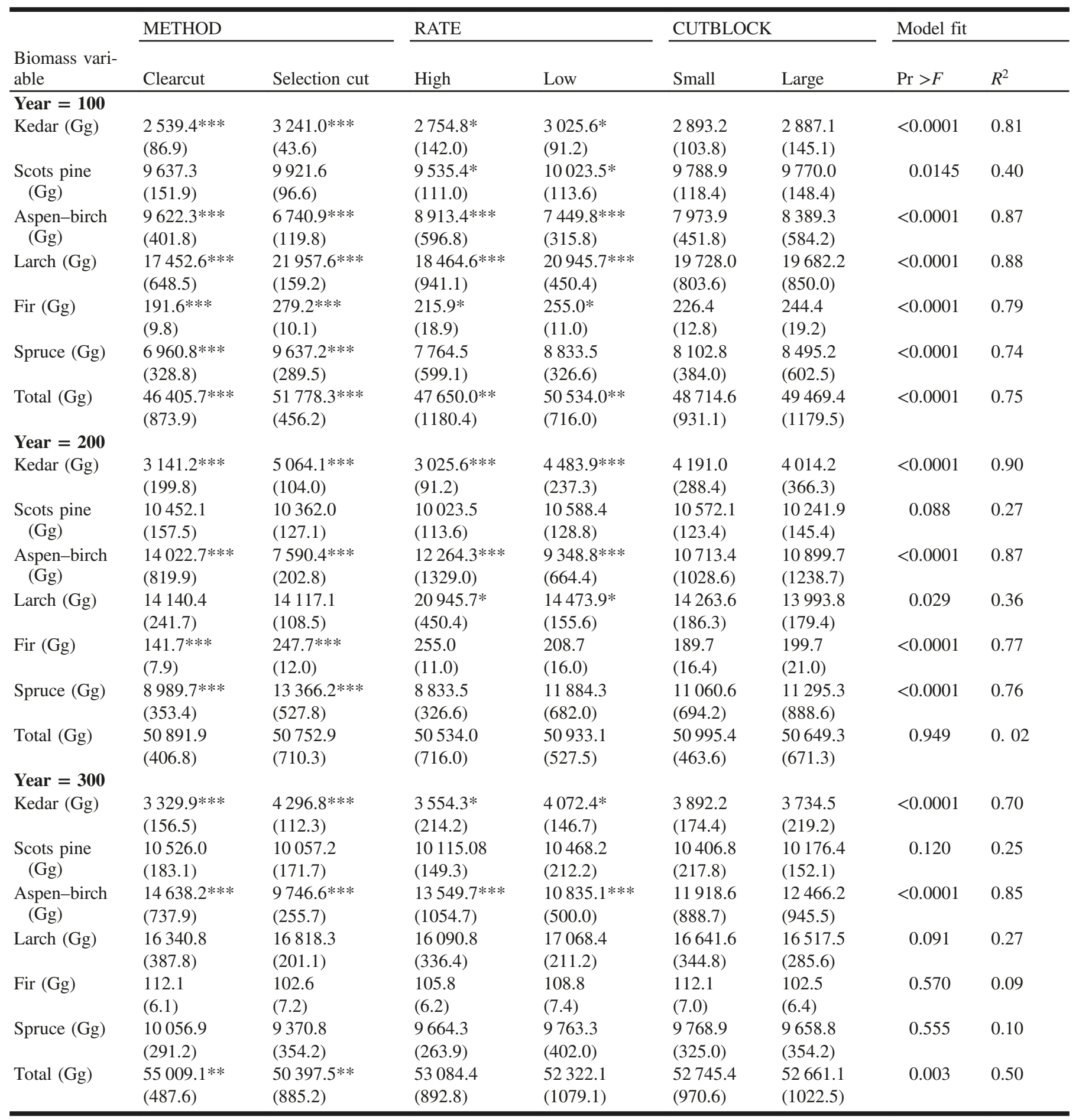

Note: Significant differences between treatment levels are indicated by asterisks: *, $P \leq 0.01$; *, $P \leq 0.001$; **, $P \leq 0.0001$. The variable "Total" is the sum of all species biomass and was analyzed in a separate ANOVA model.

high variability and the unknown effects of future climate. The harvest parameters were set as experimental treatments. Another source of uncertainty is in the specification of the model itself. After conducting a sensitivity analysis of LANDIS-II parameters in the study area, Gustafson et al. (2010) concluded that most of the sensitive parameters were well established empirically. Furthermore, the model is proc- ess-based, and the specification of those processes comes from empirically based findings in the literature. Although the specifics of forest dynamics in space and time should be viewed cautiously, the general response of the landscape to the treatments can be given credence, given our current understanding of disturbance and succession in boreal forest ecosystems. 
Fig. 3. Effects on forest biomass (living aboveground biomass plus biomass removed by harvesting) through time by the METHOD and RATE treatments. The CUTBLOCK treatment was pooled for these graphs because it did not have a significant effect on these variables. Note that the abundance of fir was so low that it is essentially invisible in these graphs.
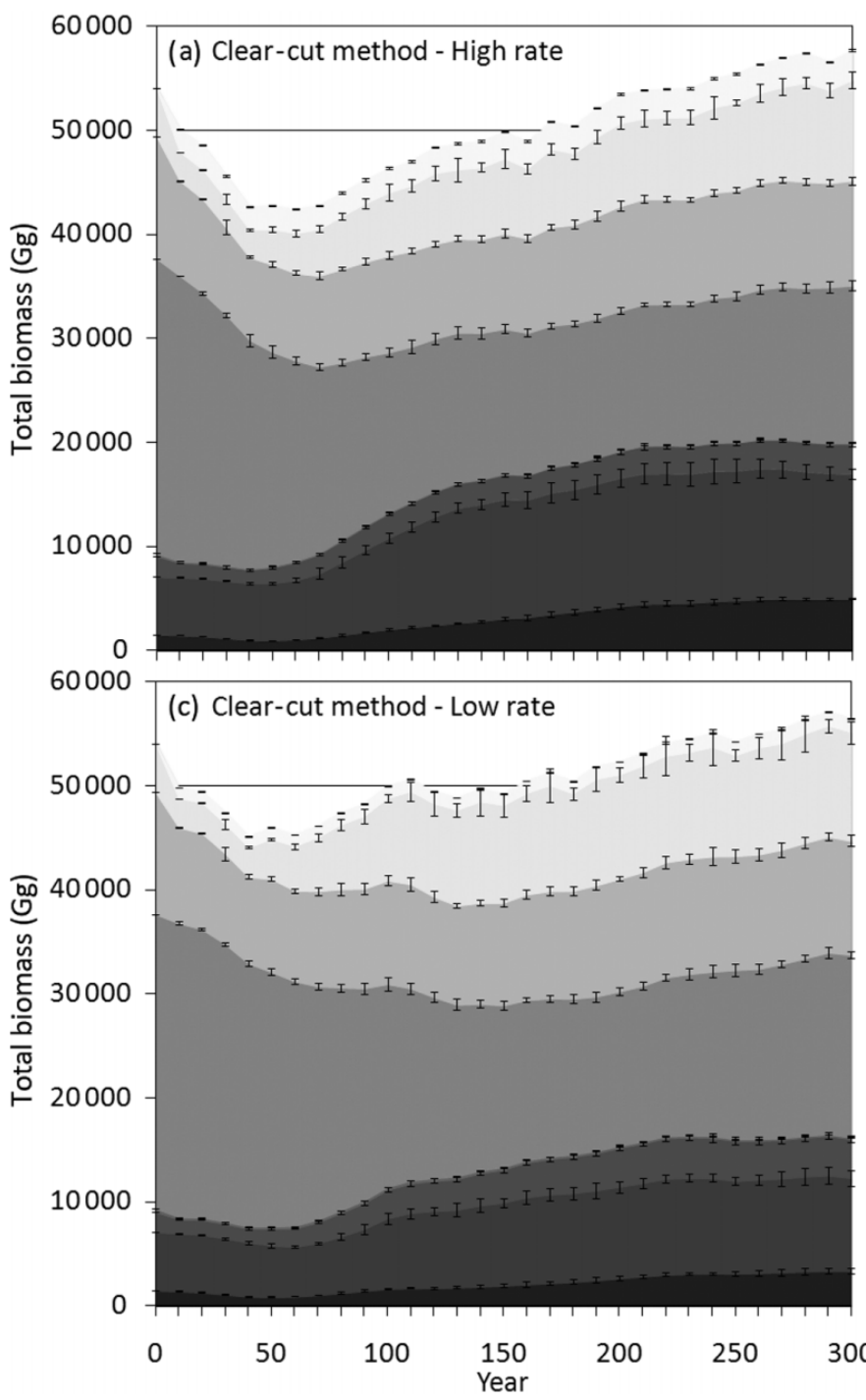

Our simulation approach assumes that climate change affects only vegetation succession (through establishment probabilities and species' growth rates) and disturbance behavior (through changes in temperature and precipitation). Changes in these characteristics and their interactions were assumed not to push the system across any thresholds of behavior such that the simulated processes behave dramatically differently than they do under current conditions. Also, $\mathrm{CO}_{2}$ fertilization effects (Norby et al. 2005) were ignored. It is difficult to judge scientifically if these assumptions are reasonable because such climatic conditions have not yet been observed in this ecosystem. However, our results show the expected behavior of the system given these assumptions, and as such, they provide some insight into the potential effects of management strategies in the face of global change.

Our experiment examined the effects of highly generalized management strategies to provide general insight into their relative ability to manage forests in the face of global change. Because these strategies contain none of the precision that
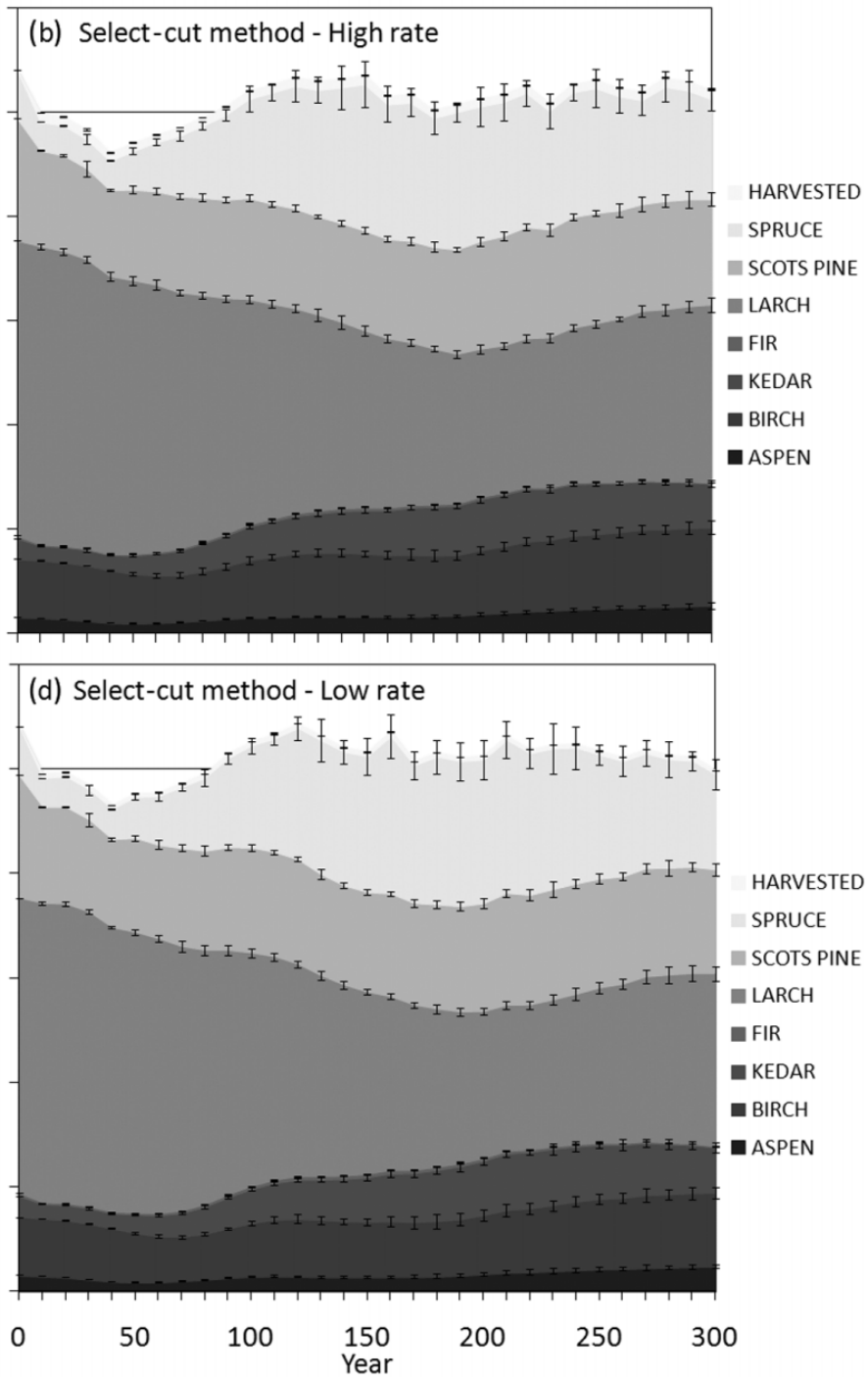

foresters use to target silvicultural prescriptions to specific stand conditions and because of the uncertainties inherent in the modeling procedure, we looked for highly significant tendencies and gave little credence to marginal relationships (those with $p>0.01$ ). In terms of the effects of the strategies on shade-tolerant vs. shade-intolerant species, our results can be considered quite general. In terms of geography, the study area is representative of much of south-central Siberia, and our results are likely relevant to landscapes containing the same species and no permafrost. Our results may be applicable to other boreal systems, but additional research is necessary to explore the variability of responses among ecosystems.

How do our results inform the questions posed in the Introduction?

1. What is the relative effect of various silvicultural techniques on forest composition, standing biomass and landscape pattern? The results indicate the sign (positive or 


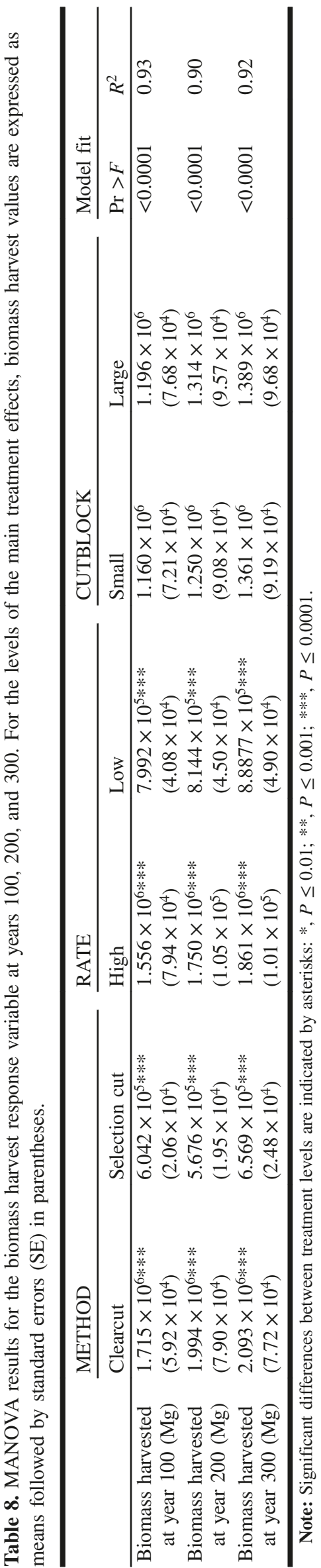

negative) of the effect of a given treatment level and provide an indication of how stable the effect is through time. This information can provide some insight into questions of how management actions might be used to mitigate negative effects of harvesting on ecosystem sustainability in the face of global change. As might be expected, the answer depends on the management objective, and there appears to be no single management approach that is optimal for all desired outcomes.

2. Can silviculture reduce the susceptibility of forests to natural disturbance (wildfire and silk moth) under future climate conditions? Our results suggest that a high cutting rate using clearcutting would be the most effective (by reducing average stand age and converting some conifers to deciduous), although the effect of silvicultural strategies on fire are weak. However, such a strategy may conflict with other silvicultural and ecological management objectives. For example, micrometeorological conditions on large clearcut areas inhibit regeneration and growth of forests during the early succession stages (Melekhov 1989). In comparison, Ravenscroft et al. (2010) found that although silviculture designed to mimic the HRNV was effective at slowing change under a "mild" climatechange scenario, more extreme climatic changes negated any effects of silviculture.

3. Can management increase forest productivity under future climate and disturbance regimes? All experimental treatments produced a marked decline in forest biomass (total AGB plus removed biomass) in the first 50 years (Fig. 3). Forest biomass increased after that, with the increase being more rapid under selection cutting than under clearcutting. However, only clearcutting generated biomass higher than the initial levels (after year 200). Biomass gains came primarily from aspen, birch, spruce, and Scots pine under clearcutting and from kedar and spruce under selection cutting (Fig. 3). The value of these gains might depend on the management objectives (e.g., commercial harvest vs. carbon sequestration). Interestingly, clearcutting initially increased the abundance of Scots pine, but by year 300 , it was selection cutting at a lower rate that produced a higher abundance of Scots pine (Table 4). Larch, a potentially valuable species because of its resistance to insect mortality and its fire tolerance, was also more abundant under a low rate of selection cutting. Aspen and birch flourished under a clearcutting regime under future climate, and it served to lessen the impact of fire and insects on the landscape. However, sites maintained in early successional deciduous species may be vulnerable to nutrient depletion and periodic drought. If markets were developed for aspen and birch, management for these species could reduce losses to fire and insects, but unintended consequences may result. Alternatively, kedar is a species that has traditionally been highly valued in Siberia, but its abundance was increased only by selection cutting at a low rate.

4. What are the effects of silvicultural strategy on carbon sequestration? Surprisingly, our results showed that clearcutting at high rates reduced landscape biomass only in the first century, and the advantage of less intense selection cutting disappeared after that (Fig. 3). The recommended scenario produced higher amounts of biomass 
Table 9. Forest composition (proportion of species and age classes) found historically on uncut landscapes similar to the study area (HRNV) and under the "business-as-usual" and "recommended" timber management strategies. HRNV values are from Gustafson et al. (2010). Values for the simulated strategies are the range of relative area of each class found in the study area between simulation years $100-300$.

\begin{tabular}{|c|c|c|c|}
\hline Forest composition & HRNV & Business-as-usual & Recommended \\
\hline \multicolumn{4}{|l|}{ Species } \\
\hline Siberian spruce $(\%)$ & $6-25$ & $2.2-2.9$ & $3.7-4.8$ \\
\hline Siberian fir (\%) & $5-10$ & $0.1-0.2$ & $0.1-0.4$ \\
\hline Siberian larch (\%) & $15-35$ & $19.9-35.5$ & $24.7-41.2$ \\
\hline Scots pine $(\%)$ & $20-40$ & $24.9-29.0$ & $22.2-24.4$ \\
\hline $\operatorname{Kedar}(\%)$ & $7-14$ & $2.6-4.4$ & $4.4-8.9$ \\
\hline Aspen-birch (\%) & $8-30$ & $33.2-48.0$ & $25.0-38.2$ \\
\hline \multicolumn{4}{|l|}{ Age class } \\
\hline Establishment ( $1-40$ years) $(\%)$ & $5-15$ & $33.4-41.7$ & $24.5-30.7$ \\
\hline Early-seral (41-100 years) (\%) & $5-25$ & $17.9-30.6$ & $13.6-23.8$ \\
\hline Mid-seral (101-140 years) $(\%)$ & $5-20$ & $6.5-17.1$ & $8.0-16.2$ \\
\hline Late-seral (141-180 years) (\%) & $10-30$ & $7.2-13.5$ & $9.6-15.4$ \\
\hline Old-growth (>180 years) $(\%)$ & $40-65$ & $8.4-26.9$ & $17.2-35.2$ \\
\hline
\end{tabular}

Fig. 4. Forest biomass (living aboveground biomass across the entire study area plus biomass removed by harvesting) through time for the "recommended" and "business-as-usual" scenarios. Note that the abundance of fir was so low that it is essentially invisible in these graphs.

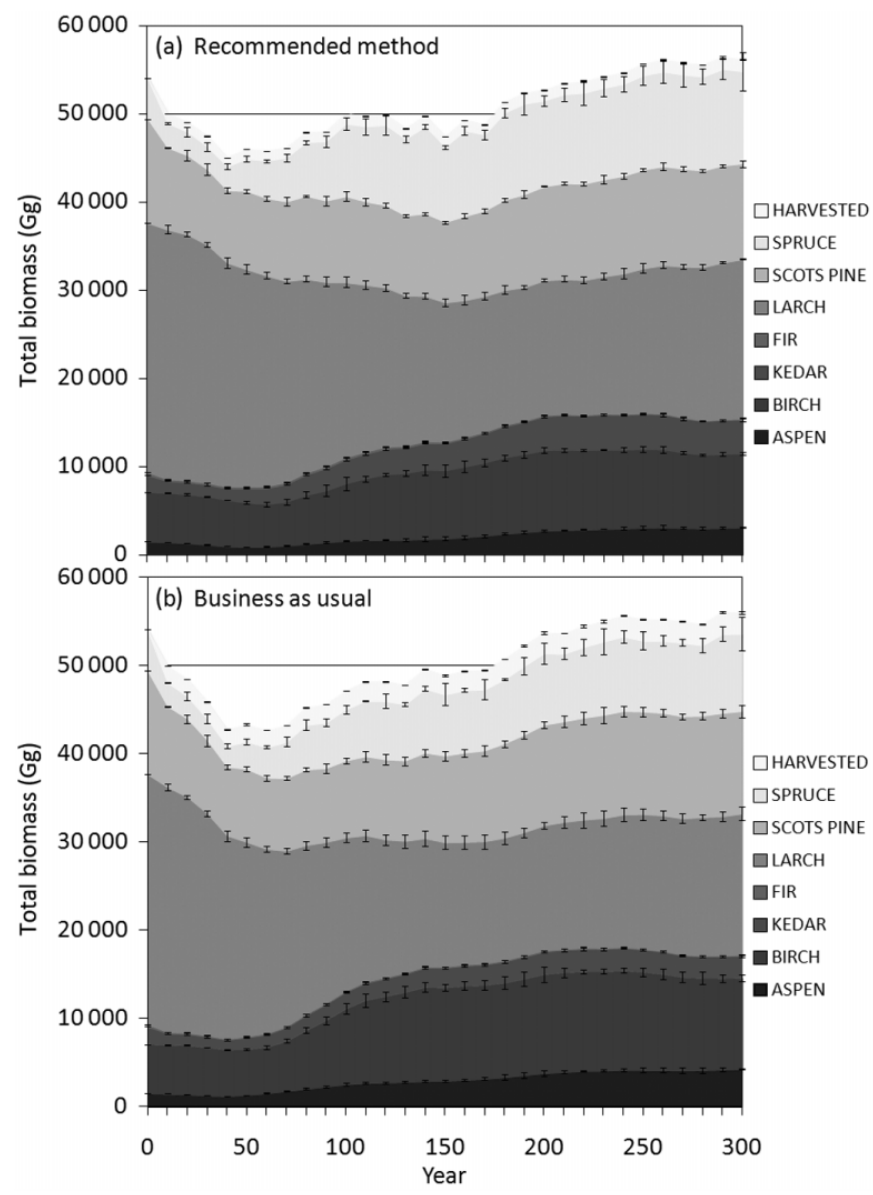

through time compared with the business-as-usual scenario, although the difference disappeared after year 250 (Fig. 4). The biomass of spruce, larch, and kedar were also significantly higher under the recommended scenario. It should be noted that our assessment of carbon impacts is partial because we did not include belowground biomass or account for the fate of carbon removed by timber harvest.

5. Can management actions effectively keep ecosystem dynamics within the HRNV? While the recommended strategy did not keep the system within the estimated HRNV for all variables (Table 9), it did a better job than the business-as-usual strategy. It is likely that there exists a management strategy that can keep the system within the HRNV. However, our recommended strategy suggests that it may be difficult to achieve HRNV conditions while also harvesting significant amounts of timber.

As is often the case, there is no single management strategy that achieves all of the many potential objectives for forested ecosystems (e.g., Hansen et al. 1995; Seidl et al. 2007). For example, the cutting method that best reduced the risk of disturbance (clearcutting), greatly increased the abundance of species that have less commercial value (e.g., aspen and birch), and the conifer species least affected by silk moth (larch) is less well adapted to the climate predicted for the future. Although our results do not help answer the question of which competing objectives should receive priority, they do provide insight into which strategies can be most effective in meeting objectives that have been established and the extent of the consequences for other, lower priority forest characteristics.

Our results relative to effects of climate change are contrary to those of some simpler models that predict dramatic deterioration of southern Siberia forests due to climate change by the end of the 21 th century. For example, the $\mathrm{Si}$ berian bioclimatic model within the climate-change scenario HadCM3GGal predicts an almost complete disappearance of taiga forests in the study region and replacement by foreststeppe and steppe landscapes (Vygodskaya et al. 2007). The simpler model is based on only three climatic indicators (growing degree days $>5{ }^{\circ} \mathrm{C}\left(\mathrm{GDD}_{5}\right)$; negative degree days (NDD), i.e., degree days $<0{ }^{\circ} \mathrm{C}$; annual moisture index $=$ 
$\mathrm{GDD}_{5}$ / annual precipitation). This discrepancy likely results from differences in model complexity and model assumptions. Our process-based modeling approach should produce greater precision and account for important interactions that may confound simpler, empirical methods. However, some of the models used to estimate LANDIS-II parameters have not been widely applied in Siberian systems. These discrepancies suggest that further research is needed to reliably make predictions about the response of Siberian forests to climate change.

From our study, we draw the following conclusions. (i) Productivity is affected by harvest METHOD. Clearcutting reduces productivity in the short term but increases it over the long term (>200 years). The long-term increases are likely related to changes in species composition, and some of the more productive species may not be those of greatest commercial value. (ii) It appears that forest management has limited power to reduce total losses to disturbance because the species most likely to reduce disturbance rates are not currently economically valuable. Silviculture can have an effect on losses by a single disturbance type but not all types simultaneously. (iii) Cutting method has a large effect on composition, and the preferred cutting method would be determined by the objectives of the manager. (iv) The usefulness of the recommended strategy is equivocal because there is no clear advantage for most management objectives. Our results also provide an incomplete picture of $\mathrm{C}$ sequestration potential because belowground carbon was not tracked. The next research step would be to have Russian forest managers develop more precise silvicultural alternatives designed to meet their specific objectives and use LANDIS-II to explore the ability of the alternatives to meet the objectives. (v) Cutblock size seems to have little effect except on fragmentation (see also Radeloff et al. 2006), so it can be used to achieve fragmentation objectives without fear of compromising other objectives. (vi) Although our results do not point to a clear, universal management solution to sustaining healthy forests in south-central Siberia, they do provide insight into the direction and magnitude of the effects of very general strategies in the face of climate change and interacting disturbances. This insight is not readily available elsewhere.

\section{Acknowledgements}

We thank Sue Lietz for providing invaluable technical support. We also thank John Brissette, Brian Palik, Mark Twery, and three anonymous reviewers for providing constructive reviews of the manuscript. Funding provided by the USDA Forest Service Northern Research Station and the International Institute for Applied Systems Analysis.

\section{References}

Aber, J.D., Ollinger, S.V., Federer, C.A., Reich, P.B., Goulden, M.L., Kicklighter, D.W., Mellilo, J.M., and Lathrop, R.G. 1995. Predicting the effects of climate change on water yield and forest production in the northeastern United States. Clim. Res. 5: 207222.

Baltzer, H., George, C., Rowland, C., Gerard, F., McCallum, I., Shvidenko, A., and Schmullius, C. 2004. Forest fires in Central Siberia and their impact on emissions of greenhouse gasses. In Proceedings of the Remote Sensing and Photogrammetric Society, Aberdeen, Scotland, 6-10 September 2004. The Remote Sensing and Photogrammetry Society, c/o School of Geography, The University of Nottingham, University Park, Nottingham, NG7 2RD, UK. CD-ROM.

Betts, R., Gornall, J., Hughes, J., Kaye, N., McNeall, D., and Wiltshire, A. 2008. Forest and emission: a contribution to the Eliasch Review. Report Prepared for Office of Climate Change by the Met Office Hadley Centre, Exeter, Devon, UK.

Delworth, T.L., Broccoli, A.J., Rosati, A., Stouffer, R.J., Balaji, V., Beesley, J.A., Cooke, W.F., Dixon, K.W., Dunne, J., Dunne, K.A., Durachta, J.W., Findell, K.L., Ginoux, P., Gnanadesikan, A., Gordon, C.T., Griffies, S.M., Gudgel, R., Harrison, M.J., Held, I.M., Hemler, R.S., Horowitz, L.W., Klein, S.A., Knutson, T.R., Kushner, P.J., Langenhorst, A.R., Lee, H.-C., Lin, S.-J., Lu, J., Malyshev, S.L., Milly, P.C.D., Ramaswamy, V., Russell, J., Schwarzkopf, M.D., Shevliakova, E., Sirutis, J.J., Spelman, M.J., Stern, W.F., Winton, M., Wittenberg, A.T., Wyman, B., Zeng, F., and Zhang, R. 2006. GFDL's CM2 global coupled climate models. Part I: Formulation and simulation characteristics. J. Clim. 19(5): 643-674. doi:10.1175/JCLI3629.1.

Forestry Canada Fire Danger Group. 1992. Development and structure of the Canadian Forest Fire Behavior Prediction System. Forestry Canada Science and Sustainable Development Directorate, Ottawa, Ontario, Information Rep. ST-X-3.

Giorgetta, M.A., Brasseur, G.P., Roeckner, E., and Marotzke, J. 2006. Preface to special section on climate models at the Max Planck Institute for Meteorology. J. Clim. 19(16): 3769-3770. doi:10. 1175/JCLI9023.1.

Gordon, C., Cooper, C., Senior, C.A., Banks, H., Gregory, J.M., Johns, T.C., Mitchell, J.F.B., and Wood, R.A. 2000. The simulation of SST, sea ice extents and ocean heat transports in a version of the Hadley Centre coupled model without flux adjustments. Clim. Dyn. 16(2-3): 147-168. doi:10.1007/ s003820050010.

Gustafson, E.J. 2007. Relative influence of major components of timber harvest strategies on landscape pattern. For. Sci. 53: 556561.

Gustafson, E.J., and Crow, T.R. 1994. Modeling the effects of forest harvesting on landscape structure and the spatial distribution of cowbird brood parasitism. Landsc. Ecol. 9(4): 237-248. doi:10. 1007/BF00129235.

Gustafson, E.J., Shifley, S.R., Mladenoff, D.J., Nimerfro, K.K., and He, H.S. 2000. Spatial simulation of forest succession and timber harvesting using LANDIS. Can. J. For. Res. 30(1): 32-43. doi:10. 1139/x99-188.

Gustafson, E.J., Shvidenko, A.Z., Sturtevant, B.R., and Scheller, R.M. 2010. Predicting global change effects on forest biomass and composition in south-central Siberia. Ecol. Appl. 20(3): 700-715. doi:10.1890/08-1693.1. PMID:20437957.

Gustafson, E.J., Shvidenko, A.Z., Sturtevant, B.R., and Scheller, R.M. 2011. Using landscape disturbance and succession models to support forest management. In Landscape ecology in forest management and conservation. Edited by C. Li, R. Lafortezza, and J. Chen. Jointly published by HEP and Springer, Beijing and Berlin. pp. 99-118.

Hansen, A.J., Garman, S.L., Weigand, J.F., Urban, D.L., McComb, W.C., and Raphael, M.G. 1995. Alternative silvicultural regimes in the Pacific Northwest: simulations of ecological and economic effects. Ecol. Appl. 5(3): 535-554. doi:10.2307/1941965.

He, H.S., DeZonia, B.E., and Mladenoff, D.J. 2000. An aggregation index (AI) to quantify spatial patterns of landscapes. Landsc. Ecol. 15(7): 591-601. doi:10.1023/A:1008102521322.

Hom, J. 2003. Soil carbon in permafrost-dominated boreal forests. In The potential of US forest soils to sequester carbon and mitigate the greenhouse effect. Edited by J.M. Kimble, L.S. Heath, R.A. 
Birdsey, and R. Lal. CRC Press, Boca Raton, Florida. pp. 259278.

Intergovernmental Panel on Climate Change. 2007. Climate change 2007: the physical science basis. In Contribution of Working Group I to the Fourth Assessment Report of the Intergovernmental Panel on Climate Change. Edited by S. Solomon, D. Qin, M. Manning, Z. Chen, M. Marquis, K.B. Averyt, M. Tignor, and H.L. Miller. Cambridge University Press, Cambridge, UK.

Johnson, R.A., and Wichern, D.W. 1992. Applied multivariate statistical analysis. Prentice Hall, Englewood Cliffs, New Jersey.

Juday, G.P., Barber, V., Vaganov, E., Rupp, S., Sparrow, S., Yarie, J., Linderholm, H., Berg, E., D’Arrigo, R., Duffy, P., Eggertsson, O., Furyaev, V.V., Hogg, E.H., Huttunen, S., Jacoby, G., Kaplunov, V.Ya., Kellomaki, S., Kirdyanov, A.V., Lewis, C.E., Linder, S., Naurzbaev, M.M., Pleshikov, F.I., Runesson, U.T., Savva, Yu.V., Sidorova, O.V., Stakanov, V.D., Tchebakova, N.M., Valendik, E.N., Vedrova, E.F., and Wilmking, M. 2005. Forests, land management, agriculture. In Arctic Climate Impact Assessment. Edited by C. Symon, L. Arris, and B. Heal. Cambridge University Press, Cambridge, UK. pp. 781-862.

Kolesnichenko, V.T., Ufimtseva, K.A., Kuzmin, V.A., and Korzun, M.A. 1988. Soil map of the Irkutsk oblast. State Committee on Geodesy and Cartography of the USSR, Moscow, Russia. [In Russian.]

Malevsky-Malevich, S.P., Molkentin, E.K., Nadyozhina, E.D., and Shklyarevich, O.B. 2008. An assessment of potential change in wildfire activity in the Russian boreal forest zone induced by climate warming during the twenty-first century. Clim. Change, 86(3-4): 463-474. doi:10.1007/s10584-007-9295-7.

McFarlane, N.A., Scinocca, J.F., Lazare, M., Harvey, R., Verseghy, D., and Li, J. 2005. The CCCma third generation atmospheric general circulation model. Canadian Centre for Climate Modelling and Analysis, University of Victoria, Victoria, British Columbia, Canada, Internal Report.

Melekhov, I.S. 1989. Final felling. Agropromizdat Publisher, Moscow, Russia. [In Russian.]

Meleshko, V.P., Kattsov, V.M., Govorkova, V.A., Sporyshev, P.V., Shkol'nik, I.M., and Shneerov, B.E. 2008. Climate of Russia in the 21 st century. Part 3. Future climate changes calculated with an ensemble of the coupled atmosphere-ocean General Circulation CMIP3 Models. Russian Meteorol. Hydrol. 33(9): 541-552. doi:10.3103/S106837390809001X.

Miller, J.D., Safford, H.D., Crimmins, M., and Thode, A.E. 2009. Quantitative evidence for increasing forest fire severity in the Sierra Nevada and Southern Cascade Mountains, California, and Nevada, USA. Ecosystems (N.Y.), 12(1): 16-32. doi:10.1007/ s10021-008-9201-9.

Milne, E., Aspinall, R.J., and Veldkamp, T.A. 2009. Integrated modelling of natural and social systems in land change science. Landsc. Ecol. 24(9): 1145-1147. doi:10.1007/s10980-009-9392-2.

Mladenoff, D.J. 2004. LANDIS and forest landscape models. Ecol. Model. 180(1): 7-19. doi:10.1016/j.ecolmodel.2004.03.016.

Ministry of Natural Resources of the Russian Federation. $2007 a$. Procedure for estimating the annual allowable cut. Approved by the Ministry of Natural Resources of the Russian Federation, 8 June 2007, N 148. Available in Russian from http://www. forestforum.ru/ [accessed 8 March 2010].

Ministry of Natural Resources of the Russian Federation. 2007b. Rules of harvest of wood in forests of the Russian Federation. Approved by the Ministry of Natural Resources of the Russian Federation, 16 July 2007, N 184. Available in Russian from http:// www.forestforum.ru/ [accessed 8 March 2010].

Norby, R.J., DeLucia, E.H., Gielen, B., Calfapietra, C., Giardina, C.P., King, J.S., Ledford, J., McCarthy, H.R., Moore, D.J.P.,
Ceulemans, R., De Angelis, P., Finzi, A.C., Karnosky, D.F., Kubiske, M.E., Lukac, M., Pregitzer, K.S., Scarascia-Mugnozza, G.E., Schlesinger, W.H., and Oren, R. 2005. Forest response to elevated $\mathrm{CO}_{2}$ is conserved across a broad range of productivity. Proc. Natl. Acad. Sci. U.S.A. 102(50): 18052-18056. doi:10. 1073/pnas.0509478102. PMID:16330779.

Onuchin, A.A. (Editor). 2007. Sustainable forest management: challenges at a regional level. Institute of Forest, Siberian Branch of the Russian Academy of Science, Krasnoyarsk, Russia. [In Russian.]

Radeloff, V.C., Mladenoff, D.J., Gustafson, E.J., Scheller, R.M., Zollner, P.A., He, H.S., and Akçakaya, H.R. 2006. Modeling forest harvesting effects on landscape pattern in a fire-adapted ecosystem. For. Ecol. Manage. 236(1): 113-126. doi:10.1016/j. foreco.2006.09.007.

Ravenscroft, C., Scheller, R.M., Mladenoff, D.J., and White, M.A. 2010. Forest restoration in a mixed-ownership landscape under climate change. Ecol. Appl. 20(2): 327-346. doi:10.1890/08-1698. 1. PMID:20405791.

Ripple, W.J., Bradshaw, G.A., and Spies, T.A. 1991. Measuring forest landscape patterns in the Cascade Range of Oregon, USA. Biol. Conserv. 57(1): 73-88. doi:10.1016/0006-3207(91)90108-L.

SAS Institute Inc. 2008. SAS for Windows. SAS Institute Inc., Cary, North Carolina.

Scheller, R.M., and Mladenoff, D.J. 2004. A forest growth and biomass module for a landscape simulation model, LANDIS: design, validation, and application. Ecol. Model. 180(1): 211-229. doi:10.1016/j.ecolmodel.2004.01.022.

Scheller, R.M., Domingo, J.B., Sturtevant, B.R., Williams, J.S., Rudy, A., Gustafson, E.J., and Mladenoff, D.J. 2007a. Design, development, and application of LANDIS-II, a spatial landscape simulation model with flexible temporal and spatial resolution. Ecol. Model. 201(3-4): 409-419. doi:10.1016/j.ecolmodel.2006. 10.009.

Scheller, R.M., Domingo, J.B., and Miranda, B.R. 2007b. LANDIS-II base wind extension (version 1.3): user guide [online]. Available from http://www.landis-ii.org/exts/wind [accessed 8 March 2010].

Sedykh, V.N. 2009. Forest forming process. Nauka, Novosibirsk, Russia. [In Russian.]

Seidl, R., Rammer, W., Jager, D., Currie, W.S., and Lexer, M.J. 2007. Assessing trade-offs between carbon sequestration and timber production within a framework of multi-purpose forestry in Austria. For. Ecol. Manage. 248(1-2): 64-79. doi:10.1016/j. foreco.2007.02.035.

Shvidenko, A., McCallum, I., and Nilsson, S. 2005. Data, results and assessments of full greenhouse gas accounting for the major GHG's for 2002-2003. Report on project Siberia II (Multi-sensor concept for greenhouse gas accounting in northern Eurasia), Fifth Framework Programme, Generic Activity 7.2: Development of Generic Earth Observation Technologies, Laxenburg, Austria.

Soja, A.J., Tchebakova, N.M., French, N.H.F., Flannigan, M.D., Shugart, H.H., Stocks, B.J., Sukhinin, A.I., Parfenova, E.I., Chapin, F.S., III, and Stackhouse, P.W., Jr. 2007. Climate-induced boreal forest change: predictions versus current observations. Global Planet. Change, 56(3-4): 274-296. doi:10.1016/j. gloplacha.2006.07.028.

Sturtevant, B.R., Gustafson, E.J., Li, V.W., and He, H.S. 2004. Modeling biological disturbances in LANDIS: a module description and demonstration using spruce budworm. Ecol. Model. 180(1): 153-174. doi:10.1016/j.ecolmodel.2004.01.021.

Sturtevant, B.R., Miranda, B.R., Scheller, R.M., and Shinneman, D. 2009. LANDIS-II dynamic fuels and fire system extensions (version 1.0): user guide [online]. Available from http://www. 
landis-ii.org/exts/dynamic_fire_fuels_system [accessed 8 March 2010].

Udra, I.F. 1990. Settling of plants and migration of tree species in temperate zone. Academy of Sciences, Kiev, Ukraine. [In Russian.]

Van Wagner, C.E. 1987. Development and structure of the Canadian Forest Fire Weather Index System. Forestry Technical Report 35, Canadian Forest Service. Ottawa, Ontario, Canada.

Vaschuk, L.N. (Editor). 1992. Background of organization and development of forest management in the Irkutsk region. Pribaikal State Forest Inventory and Planning Enterprise, Irkutsk, Russia. [In Russian.]

Vaschuk, L.N., and Shvidenko, A.Z. 2006. Dynamics of forests of the Irkutsk region. Irkutsk Printing House No. 1, Irkutsk, Russia. [In Russian.]
Vygodskaya, N.N., Groisman, P.Y., Tchebakova, N.M., Kurbatova, J. A., Panfyorov, O., Parfenova, E.I., and Sogachev, A.F. 2007. Ecosystems and climate interactions in the boreal zone of northern Eurasia. Environ. Res. Lett. 2(4): 045033. doi:10.1088/1748-9326/ 2/4/045033.

Westerling, A.L., Hidalgo, H.G., Cayan, D.R., and Swetnam, T.W. 2006. Warming and earlier spring increase western US forest wildfire activity. Science (Washington, D.C.), 313(5789): 940943. doi:10.1126/science.1128834. PMID:16825536.

Yang, J., He, H.S., and Gustafson, E.J. 2004. A hierarchical fire frequency model to simulate temporal patterns of fire regimes in LANDIS. Ecol. Model. 180(1): 119-133. doi:10.1016/j. ecolmodel.2004.03.017. 